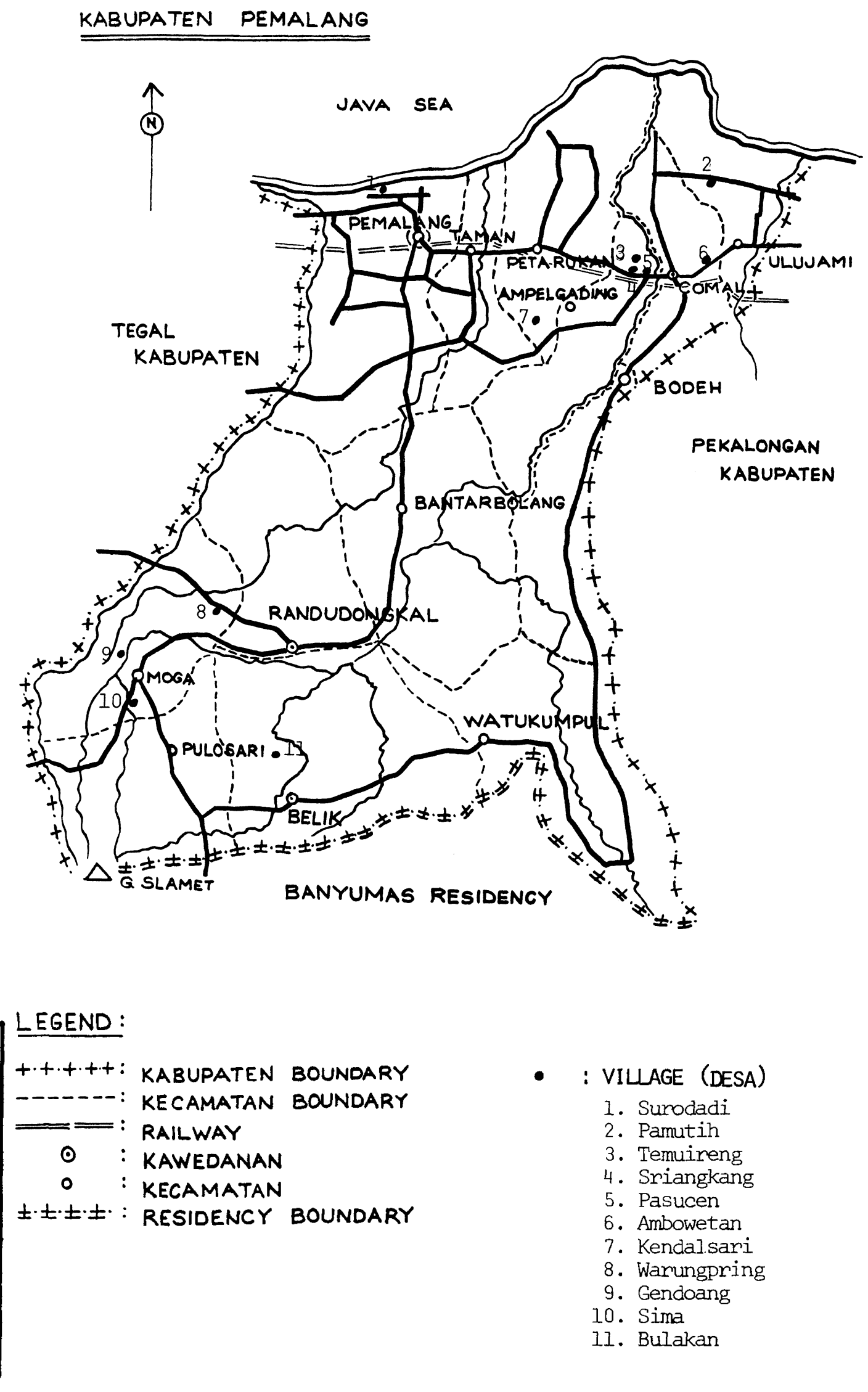




\title{
SOCIAL REVOLUTION IN PEMALANG, CENTRAL JAVA, 1945*
}

\author{
Anton Lucas
}

The social upheaval which occurred in the kabupaten (regency of Pemalang on the north coast of Central Java during the last three months of 1945 was part of a wider unrest which also shook the two neighboring kabupatèn of Tegal and Brebes. Generally remembered as the Tiga Daerah ("Three Regions") Affair, its causes, course, and aftermath have been the subject of continued speculation and controversy ever since. ${ }^{1}$ This is partly because, as Kahin reminds us, people's perceptions of any event change significantly over the years according to the "changed political context, different ideological climate, and altered social values."2 But it is also because the particular events themselves have until now never been clearly and coherently depicted. The aim of this article is to analyze the origins of the "social revolution" in Pemalang in the Dutch colonial era and the Japanese occupation, describe the upheaval itself, and analyze its most significant characteristics.

\section{Prewar Pemalang}

Pemalang, on the western pasisir (coastal area), was a large commercial center in the early sixteenth century, but thereafter gradually lost importance to its two neighbors, Tegal to the west and Pekalongan to the east. If it retains to this day an identity of its own, this identity is nonetheless partly defined by the character of these neighbors. In the colonial period, the priyayi (bureaucratic upper class) of Tegal, claiming direct linear descent from the royal house of Mata-

*It should be stressed at the start that my narrative is mainly based on people's perceptions of prewar life in Pemalang, the Japanese occupation, and the "social revolution" as recalled more than a quarter of a century later. Such perceptions should not necessarily be taken as fact. Like all firsthand accounts, they are colored by such factors as individual memory, the present status of informants, the relationship between author and informants, and the course of (Indonesian) history since the events described took place. Yet they are crucial for reconstructing the atmosphere of a vanished era.

The author would like to thank Herb Feith and Ben Anderson for their many helpful comments and suggestions on earlier drafts of this essay.

${ }^{1}$ The widely differing interpretations of the Tiga Daerah Affair are reflected in the various terms used by Indonesians when talking or writing about it; it has been called a pemberontakan (revolt) or a penyelewengan (deviation), but usually the more neutral words pergerakan (movement), perjuangan (struggle), or peristiwa (affair) are used.

${ }^{2}$ George McT. Kahin, Nationalism and Revolution in Indonesia (Ithaca: Cornel1 University Press, 1970 [1952]), p. vi. 
ram, actively discouraged marriage alliances with Pekalongan priyayi families, whom they claimed were descendants of an upstart collaborator who had helped the Dutch East India Company in Semarang. ${ }^{3}$ The impact of priyayi rivalries has been reinforced by dialect differences (the speech of Pekalongan youth will still be laughed at in the streets of Tegal and vice versa) and deeper economic contrasts. Pekalongan, the rich Residency capital, has long been a flourishing batik center and is characterized by Tegal people as a peacock which dances decoratively but (by implication) does not dare to fight. Tegal, a much poorer town of small heavy industry, is proudly likened to a wild bison which can only be mounted and ridden by someone who understands its character. Pemalang, a rich rice-growing area, is often compared to a sleek perahu (small boat) which, if the long steering oar snaps, is easily thrown about by the waves ("watang putung ing ayunan"). The people of Pemalang themselves say they can sometimes then be influenced by one side or the other, by Pekalongan or Tegal. If, however, the oar of the Pemalang perahu is steered with a firm hand, as during the Tiga Daerah Affair, it will chart its own course. A second proverbial phrase-"bende munggeng tawang," the small gong echoes in the heavens--then becomes applicable: the voice of little Pemalang is heard everywhere.

The intrusion of Western capitalism in the form of the sugarcane factories brought many changes along the western pasisir. In Pemalang these factories, most1y established in the latter part of the nineteenth century, stretched in an unbroken line across the fertile coastal plain; over a distance of 24 kilometers, five such enterprises (Sragi, Comal, Comal Baru, Petarukan, Banjardowo, and Sumberharjo) took over almost all the available rice 1 and. ${ }^{4}$

People recall that the factory administrator, referred to $10 \mathrm{cally}$ as the besar pabrik, 5 was more powerful in his area than the Resident himself. His factory police (agen polisi pabrik) had the authority to arrest and detain people just like the regular police. Arab and Chinese shopkeepers quickly clustered around the factories, and, providing credit to the Javanese at exorbitant interest rates, compounded the dislike with which the factory was regarded.6

${ }^{3}$ The Tegal priyayi's belief that they are descended directly from Mataram is strengthened by the fact that Amangkurat I, escaping from an attack on his Kartasura kraton by Trunojoyo, fell sick, died, and was buried at Tegalarum, a few kilometers south of Tegal. Suputro, Tegal Dari Masa Ke Masa (Jakarta: Kementerian Pendidikan, Pengadjaran dan Kebudajaan, Bagian Bahasa, 1969), pp. 42-44.

4The high fertility of this 1and is demonstrated by Pemalang's sugar yields, consistently among the highest in Java, and paddy production per hectare, also considerably higher than the all-Java/Madura average. See R. W. Franke, "The Green Revolution in a Javanese Village" (Ph.D. dissertation, Harvard University, 1973), p. 63.

${ }^{5}$ The expression besar pabrik is still common in villages. Although grammatically incorrect, the (mistaken) usage is referred to by Javanese as "salah kaprah bener ora lumrah" or "the mistaken (word) is used/understood by everyone, the correct one [in this case pembesar not besar] is not generally used."

${ }^{6}$ The Arabs, addressed as ndoro tuan (your honor) even by the village officials, sold tasbèh (Muslim rosaries) and perfumes, but were mainly renowned as usurers, as the still-common local phrase "koyo Arab dadi. tukang renten [becoming a money lender like an Arab]" indicates. 
For Dutch-educated Javanese, it was the racial discrimination practiced by the whites and the attitudes of the Indo-Europeans working at the factory which were most resented. The former was symbolized by the hallowed billiards room where no Javanese could go unless he was an entertainer; the latter by the Eurasians' insistence on being spoken to in high Javanese, even by Javanese associates with excellent Dutch.

During the final two decades of colonial rule, landlessness had become widespread and peasant impoverishment general. One important development was the growth of banditry. These bandits, known collectively as lenggaong (also as pencoleng [thieves], pentozan [gang leaders], or blantongan) flourished above al1 near factories, and particularly in the Comal area where the Dutch gave the nickname of anggaok to villages where the lenggaong gathered.7 The pangrèh praja, traditional Javanese civil administrators, considered appointments to the kecamatan (subdistricts) near the factories to be difficult postings, for prostitution, gambling, and drinking ciu, made from waste sugar, as well as banditry, were common pastimes.

In Comal, encircled by four cane factories (Sragi, the two in Comal, and Petarukan), farmers seldom planted rice, as almost all sawah (wet rice land) was under sugar. "The farmers were like water buffaloes, working day and night, but could scarcely get enough to eat," a nationalist leader recalis. Almost no one was well enough off to have a house made of brick, and most homes had thatched grass roofs. Villagers had been suffering from patèk (yaws or framboesia) for so long that it had become a popular local belief around Comal that one ought to contract it before one died.

In 1934, the deep popular unrest was expressed in an incident which is stili vivid in the memory of local people. A Surodadi villager smeared buffalo dung on the lights of a sugarcane factory vehicle which had broken down, and then tied it to a tree with vines. The man who had done this was arrested and tried on the charge of insulting authority. But the accused firmly denied any such intent--understandably, perhaps, since conviction would have meant a jail sentence. He insisted that he had been worried that the car would "run away and collide with someone," and so he shut its "eyes" which were bothering his children "so it wouldn't be able to see where it was going." He had used dung because there was no other damp, sticky material immediately available. In the end, he was acquitted, but only because he "confessed" to never having seen a car before or known what it was like.

${ }^{7}$ Anggaok and lenggaong mean the same thing, both deriving from the root word gaok. In Pemalang gaok means a crow (cf. burung gagak in Indonesian), i.e., a carrion-eater, reflecting the Dutch opinion and one local view that these bandits were essentially predators on the population.

${ }^{8}$ Those who related this story to me were always former members of the SR, the Sarekat Rakyat (People's Unions, organizations set up in the early 1920s for nonproletarian members of the Indonesian Communist Party), many of whom lived in and around Surodadi village. The SR had a large following in the kabupatèn, especially among primary school teachers. After the 1926 communist revolt, at least five SR members from the area were imprisoned in Pamekasan (Madura) along with local members of the VSTP, the Indonesian railwaym n's union. At least one of the latter, the leader in Comal, was even exiled to the Boven. Digul camp in New Guinea. 


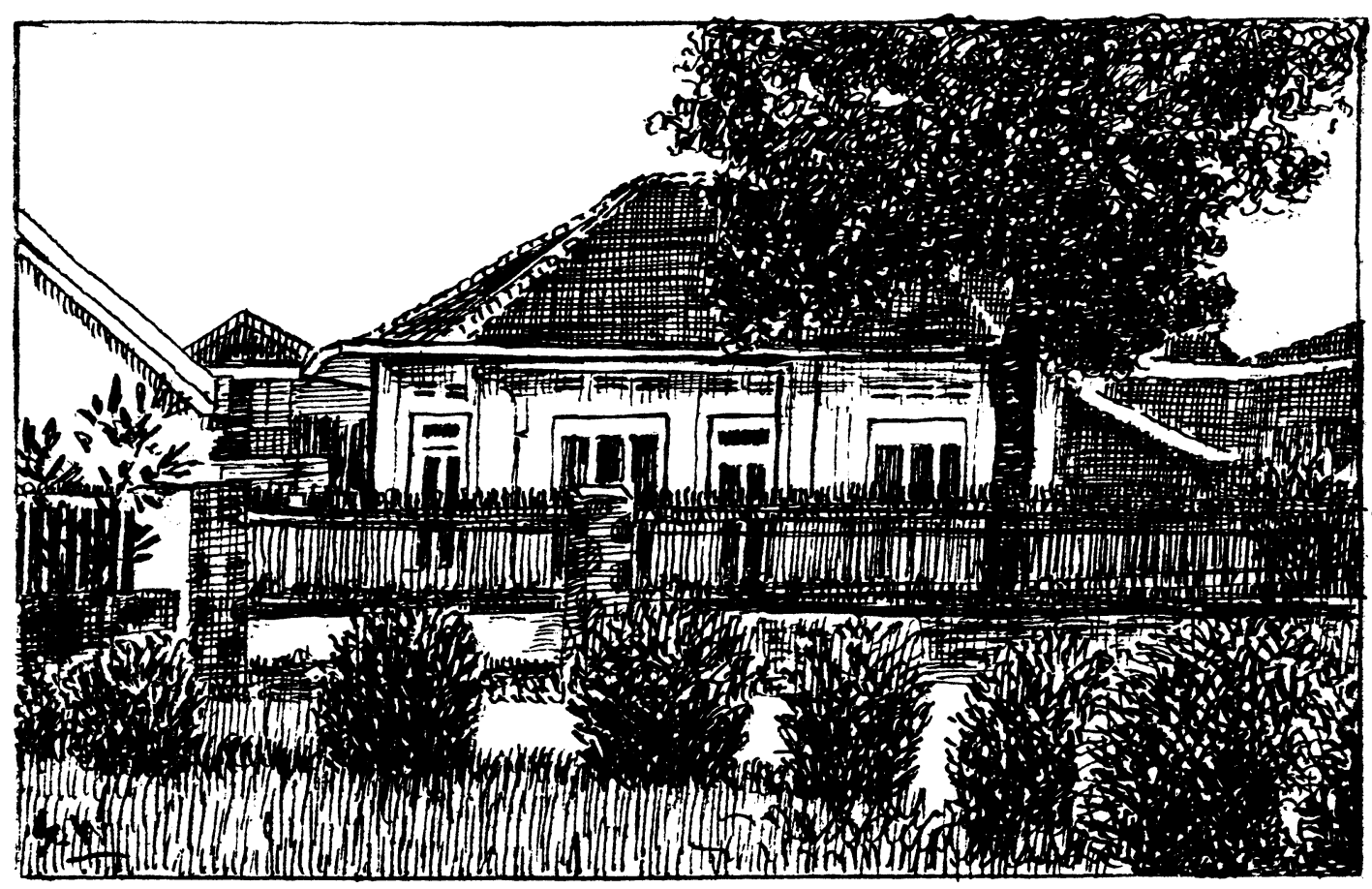

Rumah Shidokan Pemalang

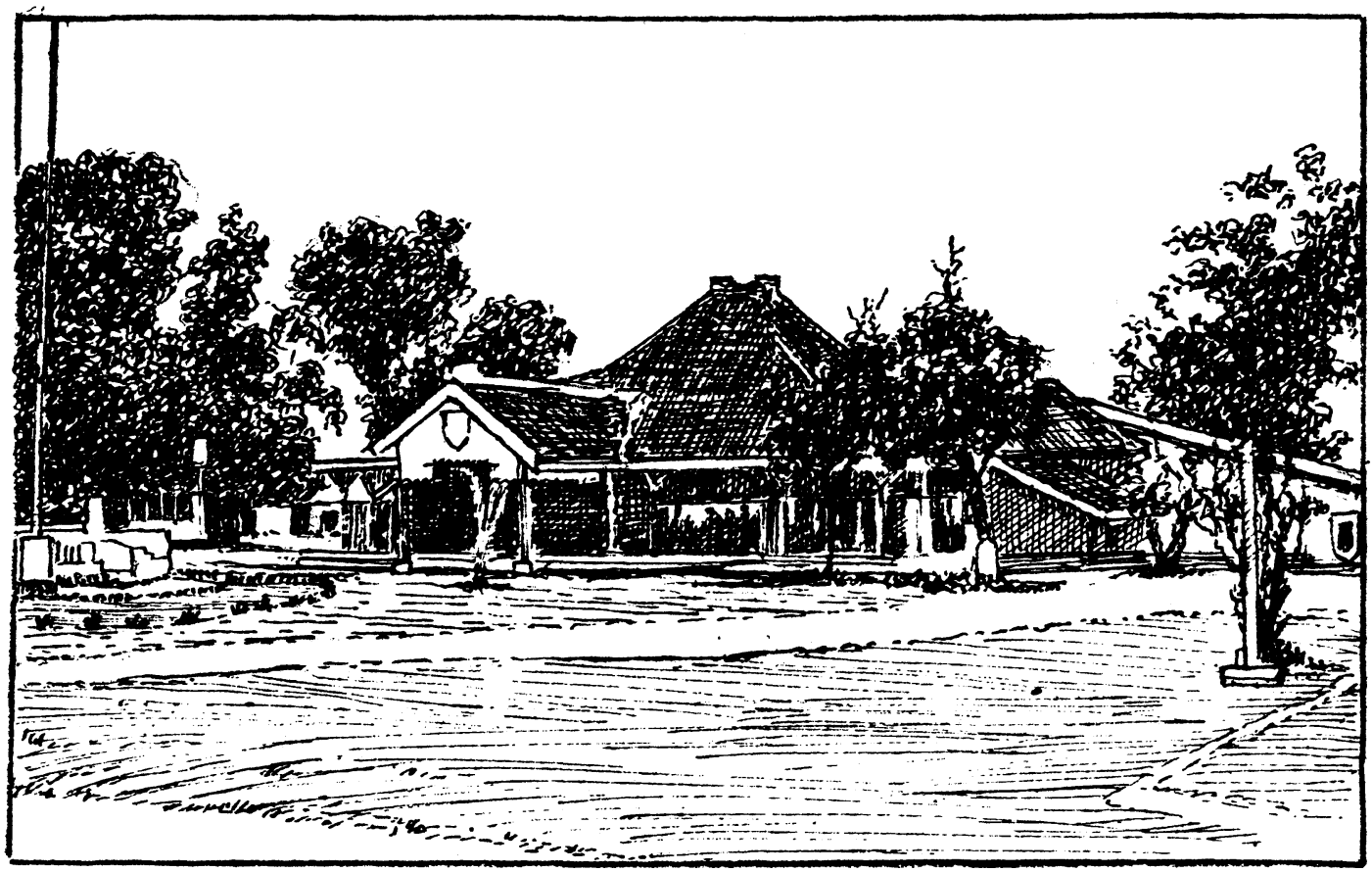

Kabupaten Pemalang

These sketches are from a collection of drawings made by Soewignjo, the AMRI Slawi leader. 
No less than on the coast, the southern hill areas of the kabupaten were marked by exploitation, popular resentment, and social disorganization. In the subdistrict of Belik, Arab traders controlled much of the arable land through their Javanese wives.9 The situation had become so bad that Dutch officials though it necessary to conduct a survey in one village of the subdistrict, Bulakan, to find out how much land was owned illegally. A nutrition survey in the subdistricts of Pulosari and Belik showed that extreme malnutrition was widespread. ${ }^{10}$ In addition, rat plagues were common, land was inefficiently cultivated by comparison to other areas, and the cassava crop was regularly spoiled or ruined by wild pigs.

In the town of Pemalang itself, there seems to have been a growing sense of class cleavage, cutting across aliran (cultural community) lines between the wong duwur (high-class people), mainly government officials and rich santiri involved in the Muhammadiyah, and the lowerclass remainder. Characteristic in this regard was the tension between the Muhammadiyah santri, physically concentrated with the priyayi in the residential kampung of Sirandu, and the so-called santri rakyat (poor santri) of Pelutan kampung, many of whom joined a cooperative led by Haji Zaini and Haji Sachroni. But the Sirandu santri, typified by Muhammadiyah leader Abdul Mutholib, his brother, who ran the Hizbul Wathan (Muhammadiyah scouts), and "Meneer" Umar, head of Muhammadiyah's Particulir Hollandsch-Inlandsche School (Private Dutch-language [primary] School for Indonesians), were hated not only by the santri rakyat of Pelutan, but also by the entire Pemalang pergerakan (national movement) as part of an elite that spoke only Dutch among themselves, lived in brick houses, played tennis with officials in the town square, and celebrated birthdays with Western-style parties.

Political life in Pemalang in the last years before the war was only to a limited degree capable of expressing popular feeling or solving the social problems it faced. Pemalang's Partindo (Partai Indonesia, Indonesia Party) leaders set up a branch of the PPKP (Persatuan Pengusaha Kaum Penganggur, the Association of Unemployed Businessmen) which tried to help small entrepreneurs out of work. A branch of the Pomer (Perhimpunan Organisasi Memajukan Ekonomi Rakyat, Association of Organizations for the Advancement of the People's Welfare), a cooperative set up by $\mathrm{Mr}$. Santosa, a prominent "cooperating" nationalist leader in Batavia, was also established.11 Many lurah had shares in

"Under the Agrarian Law of 1870, only "natives" could own arable land.

$1{ }^{\circ}$ Poelosari-Rapport. Onderzoek naar de voeding en voedings toestand der bevolking in zuid-Pemalang in 1939-41, Mededeeling No. 6 (Batavia: Instituut voor Volksvoeding, November 1941). I am grateful to Michael Williams for drawing my attention to this report. One response to these conditions was that in 1940 some priyayi officials and Zurah (village heads) formed a kebatinan (mystical) group, Mardi Utomo, which became active in the areas of health, sports, handicrafts, agriculture, and the arts. Its program included planting bamboo and tea to stop erosion, building lavatories in villages, and obtaining medicine from the government to combat the plague. It also distributed brown rice and Chinese peas to those with hunger oedema.

11"Co" (Cooperating) and "Non-Co" (Non-Cooperating) were terms widely used 
this consumers' cooperative, which was run by Sarino Mangunpranoto, then head of the local Taman Siswa. Sarino was, in fact, the most influential political figure in Pemalang at that time. Though he was not an official member of Partindo, 12 he encouraged the party, as well as Pomer and PPKP, to hold their meetings in the Taman Siswa buildings. He was also an adviser to the Pelutan cooperative and $r$ an the KBI (Kepanduan Bangsa Indonesia, Indonesian Scouts), composed mainly of Taman Siswa students.13

Because of his close personal ties with Dutch officials (the Controleur and his wife were active in the KBI, and the Assistant Resident and his wife were theosophists and admirers of $\mathrm{Ki} \mathrm{Hadjar} \mathrm{Dewantoro,}$ the founder of Taman Siswa), and the police, Pemalang's "moderate nationalists" were not harassed. Taman Siswa was never reprimanded for not flying the red, white, and blue Dutch flag on August 31 (Queen Wilhelmina's birthday), nor were any of its teachers dismissed under the "Wild School" Ordinance of 1933.

The radical nationalists, such as they were, could do little during the 1930s. Most of their efforts went into Persi (Persatuan Sopir Indonesia, Indonesian Drivers' Union), which was very active organizing oplet (small taxi bus) drivers to protect themselves against intimidation by police and the Moga Bus Company. A few of them grouped together in an organization which could do no more than gain spiritual strength by meeting regularly in the house of the kabupaten doctor, Muriawan, to discuss the question of Indonesia Merdeka (Independent Indonesia).

\section{The Japanese Occupation}

The Japanese entered Pemalang on March $17,1942^{14}$ to find the town recovering from anti-Chinese riots. There are many versions of how the berontakan Cina ${ }^{15}$ actually started. According to one account, rumors had spread that the Government pawnshop would be returning all pawned goods without charge, and so thousands of villagers poured into town

among prewar pergerakan leaders. Being "Co" meant being willing to sit in regency or provincial assemblies or in the Volksraad, the national parliament. Members of the "Co" group liked to found schools, cooperatives, and scout movements. Pomer was a typical "Co" organization, headed by a leading official, with government bureaucrats involved at all levels.

${ }_{12}$ According to a Taman Siswa rule, heads of branch schools could not join political parties, al though ordinary teachers could become members.

${ }^{13}$ The Taman Siswa and Muhammadiyah's PHIS competed fiercely for pupils, with the Sirandu PHIS teachers feeling superior to their Taman Siswa rivals. The Hizbul Wathan would have nothing to do with the KBI, on the grounds that they berbau Hindu Budha (were influenced by Hindu Buddhist practices). time.

${ }^{14}$ From the diary of Salim Bassiyul, an Arab trader living in Pemalang at the

${ }^{15}$ Again a localized term, berontakan Cina is another example of "salah kaprah bener ora lumrah" (see footnote 5). While grammatically it has to mean "revolt of the Chinese," in Pemalang the phrase (often pronounced brotaan Cina) refers specifically to the anti-Chinese riots of March 1942.. 
with receipts to claim their goods. On finding the shop guarded, the crowd began chanting "Padi dibagi! Padi dibagi! [Distribute the rice!]" and headed off to the town's three rice mills which were ransacked and had their machinery taken. As many as fifteen people were reported killed when a large paddy stack collapsed. Finally, the crowd turned on the Chinese shops and pillaged over a hundred of them. The wedana (district head) of Pemalang and the police fired shots into the air but without effect. The loot (including iron safes weighing $300 \mathrm{kilo-}$ grams) was carried back to the villages.

The most important impact of the Japanese on Pemalang derived from their desire to extract as much rice out of the peasantry as possible in order to fuel the war effort. Before the war, the Dutch had set up a rice procurement agency which provided credit for the Chinese to buy rice, which was then stockpiled. People voluntarily brought their padi (unhusked rice) to the Chinese mills for sale. There was thus no direct or obvious government control. And Dutch laws prevented anyone from stockpiling more than a ton of rice without permission. Under the Japanese, the system changed drastically. First, peasants were compelied to make set deliveries of their rice to the state. Second, once these deliveries were made, a person could stockpile as much hulled rice as space allowed. Third, whereas under the Dutch the pangrèh praja were merely tax collectors, now they had both to supervise compulsory rice deliveries and be responsible for organizing the rationing of cloth and all basic raw materials from the subdistrict level down. The most onerous part of this was that they had paddy quotas to fill and were held responsible if they were not met. As one camat (subdistrict head) put it: "The Japanese would come around every few days to see us. We were their pengawas ekonomi [economic inspectors]."

The new system involved major changes for the peasant farmer in disposal of his crop. It also gave a new role to the village heads, who became the lynchpins in a giant extractive process and thereby found new opportunities to swindle farmers. Corruption was so widespread at all levels that an old word, tanggem (meaning literally "a vice" or instrument with two jaws between which things may be gripped), was now used to refer to large-scale corruption, particularly by the camat.

The major change in the marketing of rice at the village level was that people could no longer take their harvested paddy home from the fields to hull it themselves. They now had to take it to the kalurahan (village head's house). In the subdistrict of Ulujami on the northeastern border of Pemalang, it was said that the village heads could cheat villagers in four new ways. First, when a farmer brought in his paddy, a standard weight deduction (calied repaksi) of about 25 percent was made to allow for moisture content. If the lurah decided that a farmer's paddy had a moisture content much higher than this, he simply would not accept it. When he did accept it, he would still always try to overestimate the repaksi to be able to sell the extra paddy on the black market.16

${ }^{16}$ By setting a standard 25 percent repaksi, the lurah consistently overestimated the moisture content (and thus weight deduction), which was actually nearer 23 percent. Thus he could subtract an average of three kilograms of unhusked rice for every quintal delivered. For a typical harvest in Ambowetan of about 2,880 quintals, 
Second, the lurah could obtain the jejeran gabah (fallen unhusked rice) from sheaves waiting to be weighed in front of his office. This was especially lucrative if the variety grown was padi cempo, which falls more easily out of the sheaves than does padi jowo. For every quintal delivered, the lurah could collect one kilogram of fallen gabah. ${ }^{17}$

Third, the lurah could avoid paying his quota of rice from the village sawah he tilled in lieu of salary (tanah bengkok), land which was actually included in the bureaucracy's calculations for the overall village quota. He could do this by claiming that because there had been a "crop failure" he could only supply his superiors with, e.g., 80 percent of the village quota. The lowered quota was then filled with the villagers' paddy, and the lurah could sell his own crop on the black market. ${ }^{18}$

Last1y, the scales were manipulated. Those used for weighing the paddy at the kalurahan were the colonial government's old iron dacin scales, which could weigh a maximum of 60 kilograms at a time. As it was necessary to make two weighings for every quintal, cheating was all the easier, and by underweighing the lurah could gain a kilogram or two from every quintal he weighed.

Because of these harsh conditions, more than half the farmers were forced to "steal" their own rice, usually by harvesting it secretly at night. The paddy was then buried or hidden in roof rafters. In so doing the farmers ran the dire risk of being found out by the village police and reported to the lurah or the kenpeitai (the dreaded Japanese military police). Searches for paddy by village police took place more or less every few months, with some variation depending on the subdistrict. ${ }^{19}$

In some places, evasion was fairly successful, at least when compared to official demand. For example, while the camat of Ulujami had ordered that only one quintal of paddy could be kept by a farmer from every bau harvested--about 4 percent of the average yield from good

for example, about half of which was delivered to him, the lurah could lift about 43 quintals per harvest. It is important to note that in Pemalang the weight deduction process took place at the kalurahan, not at a separate collection center. Compare the description of the lurah's role as middleman in the general account of this practice in Pekalongan Residency given in Benedict Anderson, "The Problem of Rice," Indonesia, 2 (October 1966), p. 95.

17 About half the Ambowetan harvest was padi cempo. From the gabah shaken out of the total amount of paddy delivered in one harvest he could collect a total of 14 quintals.

${ }^{18}$ In Ambowetan the lurah received 12 bau ( 0.7 hectare) of tanah bengkok with an average yield of 25 quintals per bau. With a local blackmarket price of $f .6 .00$ per kilogram (twice the Jakarta blackmarket price), compared to the official price of 10 cents per kilogram, it is clear why profiteering in rice by officials was so widespread.

19 In the Comal area people believed that the Japanese had secret telephones and a special compass which showed where paddy was being hidden. 
land--in practice only half was delivered to the kalurahan. The rest was used by the farmer himself or sold on the black market.20

From the kalurahan the paddy was either sent to the rice mill directly, or to the noji padi who sometimes helped the mill by huliing the rice on the spot.21 The latter was the system used in the U1ujami subdistrict. The paddy was sent to the village of Ambowetan where another estimate, this time of the ratio of paddy to hulled rice (beras), was made. As there were no standard weight conversion ratios set down, the noji padi could cheat by understating the amount of beras obtained from hulling a quintal of paddy. If queried by the camat, the noji padi could reply that the amount of beras was less than normal; the paddy, he would claim, was gabug (the heads were empty), either because of some disease or because, as a result of being picked too young, it had had to be made into menir (broken rice).22 On these opportunities for cheating, the former noji padi of Ulujami recalls:

I had to provide the camat of Ulujami with two quintals for his family every month. I only hulled the rice to help the rice mill and got a wage of Rp. 10 per month. I also took a small amount illegally ["saya juga tanggem kecil2an"]--about four kilograms from any one hulling for my family--but I never sold any to the middleman, as my assistants would have known; what the noji padi could do depended on tahu sama tahu [having an understanding] with his assistants. 23

While the camat could not benefit directly from illegal dealings in rice (except by taking from what was found in searches), he was directly involved in the rationing system. Throughout the Residency of Pekalongan the deliveries of rice were tied to cloth rationing. For every quintal delivered, a farmer was entitled to receive a ration of one standard-sized piece of cloth, three meters in length. In some areas, even the quality of cloth depended on the amount delivered. From a list made up at the village office of the amount of paddy delivered, the subdistrict office issued coupons to the lurah. When the cloth arrived at the subdistrict office, the carik (village secretary) was summoned to collect what cloth rations were available. There were no checks on the camat to ensure that he really distributed all the rations he received from the kabupaten. But the camat was not alone in being able to exploit the system; the lurah was also well-placed to do so, by manipulating the rice-cloth exchange as follows: If, for example, a farmer delivered less than a quintal of paddy, he did not qualify for any cloth at all; similarly, if his quota was, say, $1 \frac{1}{2}$ quintals, he would only get one standard-sized piece of cloth. In

${ }^{20}$ That farmers "stole" their own rice to sell is not surprising, considering that peasants in the Pekalongan Residency were getting only $f .1 .88$ of the $f .4 .00$ official price for each quintal. Anderson, "The Problem of Rice," p. 94.

${ }^{21}$ The noji padi was the local official responsible for paddy collection. Noji in Japanese means agricultural affairs and noji $i$ in are agricultural officials.

${ }^{22}$ The pounders (fifty were employed by the noji padi in Ambowetan), apart from getting a wage of one kilogram per quintal pounded, also kept the rice straw, the bran, and the broken grains.

${ }^{23}$ Interview with former noji in November 1975. 
short, there were no fractions of quotas permitted. The lurah then used the extra fractions of rice to collect more cloth at the kecamatan level and kept it for himself. An official appointed by the Japanese to oversee the rationing system and paddy collection at the kabupatèn level recalls the situation in some districts thus:

I saw clothing material stacked undistributed in the three kewadanaan pendopo [pavilions] of Coma1, Randudongkal, and Pemalang, which were full of cloth. In Randudongkal, where, my brother-in-law was wedana, I saw his mattresses were stuffed with clothing material instead of kapok; his pillows were also full of yarn. ${ }^{24}$

The lurah also supervised the consumer cooperatives, or kumiai, and was often "tahu sama tahu" with the cooperative head (nogyō kumiai). If there was not enough cloth to go around, the lurah was not likely to admit it. Cloth and other supplies were distributed by the nogyō kumiai through the azachō,25 each azachō being responsible for three tonari gumi (neighborhood associations), which usually corresponded to a hamlet. Delivery of supplies was quite irregular, and it was never known when they would arrive, let alone in what quantities. Actual quotas were decided on the spot by each azachō and kumichō (head of the tonari gumi) depending on what was received. Given the nature of the system, the widespread shortages, and high black market prices, it it not surprising that corruption was widespread.

Corrupt or not, officials found their position as the executors of Japanese exactions increasingly difficult and even dangerous. Towards the middle of 1943, Raden Bambang Basiroen, the over-zealous camat of Ampelgading, was himself entering houses and climbing roof rafters to look for hidden paddy. On a Friday kliwon in that year, according to one eyewitness account, a crowd of thousands gathered in front of his office, shouting in Japanese: "Atsumare! Atsumare! [Gather! Assemble!]." Not long afterwards, Basiroen was mobbed and killed with bamboo spears.26

In another incident, the carik of Pamutih (Ulujami subdistrict) tried to reason with the subdistrict police officer (mantri polisi) and his assistant to prevent them from confiscating ten sheaves of rice from a poor farmer who had been saving them for a slametan (ritual meal). 27 In his words:

The mantri took my pleas for the poor farmer the wrong way. He thought I was hampering him ["dianggap saya rintangi"]. He then confiscated about ten quintals of my paddy as well, leaving only two quintals. I had in fact delivered my quota of 15 quintals and I had a receipt to prove it. Here $I$ was being told to sell the rest of my paddy! Just because I had defended a poor farmer! I protested and an argument broke out which ended in a fight. The mantri left, but

${ }^{24}$ Interview in February 1975.

${ }^{25}$ Azachö from $a z a$ meaning hamlet, and chō, head.

${ }^{26}$ Transcript of taped interview with a former Ampelgading Seinendan (Youth Corps) leader in November 1975.

27 One sheaf of unhusked paddy is equal to about 6 kilograms of hulled rice in this area. 
later in the day a jeep arrived with a kenpeitai officer (a Japanese), and I was taken to the kenpeitai headquarters in Pekalongan. I was accused of hampering the collection of paddy and kept there for seven days. While I was there, I was beaten with a rubber whip, given electric shocks through my right hand until I fainted, and made to lie on zinc roofing in the midday sun. I was covered with a board, and people stood on top of me until I fainted. For seven days I was given only a glass of milk three times a day and nothing else to eat. At the end of seven days I was sent home. ${ }^{28}$

No social group in Pemalang society, not even the priyayi officials, was immune to Japanese violence. Raden Soewignyo Sudarsono, the district secretary, had his face pierced with the sharp point of his desk nameplate while working in the General Affairs section of the Residency office. A school teacher called Soewignyo, arrested after the kenpeitai had received an anonymous letter about him, was tortured to death in a Pekalongan jail. During the first six months of the occupation, when the district was under direct military administration, people were often manhandled on the street, as in the following incident:

I was walking past the guardpost in front of the local Japanese commander's house in the subdistrict of Pulosari, on my way to see a friend. I didn't keirei [Japanese bow, low from the waist]. I was called up and slapped across the face [ditempéléng]. The guard asked who I was, and I replied that I was a sensei [Japanese for teacher]. He was rather abashed to hear this and said that as a teacher I had to set a good example. He was only a kroco [ordinary soldier]. ${ }^{29}$

Village people bringing their produce to Pemalang's market often did not understand the rule that one had to keirei at military guardposts. They were called back, told to get off their bicycles, and hit on the head.

Yet although Japanese violence spared no social group, it is important to remember that in general the lot of villagers was far worse than that of townspeople. They did not qualify for rice rations as did government officials or other townspeople.30 In the towns, people could still get cloth, whereas gunny sacking and sarongs of rubber were generally worn in rural areas towards the end of the occupation. The sacking was full of lice, and the rubber hot, sticky, and easily torn. Cloth was so scarce that even headscarves were made into shorts. The towns still had electricity, schools, and cars; and a majority of the Western-educated elite of the district lived there. It was this group whose support the Japanese considered important, while the word genjümin, meaning "native," conjured up their view of villagers as people who did not really matter.

\section{${ }^{28}$ Interview in November 1975. $\quad{ }^{29}$ Interview in December 1974.}

${ }^{30}$ According to one official, government officials in Pemalang got 200 grams of rice per person per day. Ordinary townspeople received much less, about a kilogram per person per month, or 30 grams per person per day, distributed by the kumicho. This was not as low as in other parts of Java. See Anderson, "The Problem of Rice," p. 91 . 
Conditions in the villages during the second half of the occupation were so bad that many people were forced to eat walur, the root of a kind of nettle, which had to be sliced and soaked in brine to remove the poisonous sap. They also ate cassava, bongol (banana root nodules), and boiled bulung leaves, normally used for roof thatching. (The Japanese tried to make a virtue of necessity by encouraging the spread of new recipes using these unaccustomed ingredients.) In Pemalang, bubur perjuangan (people's struggle porridge) seems to have consisted of sweet potato, cassava, and katul.31 "It was like eating chicken feed," recalls a nationalist leader, "I wanted to vomit."

Fuel was also in short supply. What kerosene there was, was too thick to burn in lamps. Instead, people used homemade wicks in a saucer of the kerosene oil, a process which filled the house with soot. "You could rub your nose and soot would come off," they say. There were no matches or cigarette-1ighter flints; instead, various coconut tree fibers which would burn for hours were used.

Some attempts were made both by honest priyayi officials and leaders of the prewar nationalist movement to alleviate the shortages in the rural areas by forming cooperatives. One of these was Kopi (Koperasi Indonesia), founded by Sarino Mangunpranoto and based on the prewar Pomer. It included the town's top priyayi officials, with the district head (bupati) as patron, the public prosecutor as honorary head, and Abdul Mutholib, the head of Muhammadiyah, as business manager. Using the authority of the bupati, Sarino was able to raise enough capital from selling shares in Kopi to various lurah to buy supplies of soap, sugar, cloth, and cooking oil. These were distributed to each lurah according to local needs. Kopi worked smoothly until 1943, when Sarino moved to Pati; after that, it declined, as Mutholib gradually gained the reputation of being Pemalang's biggest swindler.

Kopi's main competitor was the Pekope (Penolong Korban Perang, War Victims' Helpers), a cooperative set up by "non-Co" members of the prewar nationalist movement. Led by Soepangat, Pemalang's senior medical orderly, the organization's membership included two santri leaders, H. Sanusi from Pelutan and H. Zaini from Randudongkal. Pekope also ran the Fuji restaurant, which was a favorite meeting-place for santri and nationalist leaders alike. Comments one prominent santri from near Pemalang: "I have never eaten saté like it, the spices were unrivaled." The Fuji also housed the Pemalang headquarters of the PKI underground that was based in the inland forestry plantations. It was used as an overnight stopping place for leaders of this underground, including Widarta, Seto, Kamidjaja, and Cilik, all of whom had escaped kenpeitai sweeps in Jakarta, Solo, and East Java.

By the end of the occupation, the radical nationalists came into effective leadership of the nationalist movement in Pemalang. With the departure of Sarino, a moderating and unifying influence exerted through the Taman Siswa was gone; the subsequent discrediting of Kopi, because of the corrupt activities of Mutholib and his priyayi associates, accelerated the process. By contrast, Soepangat, with his reputation for honesty, became increasingly influential as leader of

${ }^{31} \mathrm{Katul}$ is the brown skin of unpolished rice, rich in vitamin $\mathrm{Bl}$. 
the Pekope.32 Through Pekope too, Amir, a prewar PKI leader from Comal, became well known to the pemuda and the town's nationalist movement.

\section{Responses to the Proclamation}

The revolusi sosial (social revolution) in Pemalang must be seen in the context of national and residency politics of the time. The initial excitement caused by the Proclamation of Independence was followed by a month of consolidation by the nationalist leaders in Jakarta, who anticipated the rapid arrival of the Allies. One aim of the first Indonesian Republican cabinet, which lasted from September 4 until November 14 , was to show the British (who had arrived in various parts of Java by the end of October) and the rest of the world that the government had real authority over the population and commanded genuine popular support. But this aim was never really achieved. The elderly cabinet was extremely weak and soon collapsed, partly because of the revolutionary actions in regions such as Pemalang, which it could not control. The much younger syahrir cabinet, which replaced it, was just as concerned to show the Allies that, through transforming the KNIP (Komité Nasional Indonesia Pusat, Central Indonesian National Committee) from an advisory into a parliamentary legislative body and allowing the establishment of political parties, Indonesia had a democratic form of government. However, the new cabinet was no more successful than its predecessor in working out a policy towards the revolutionary actions in the local areas. Sjahrir's Perjuangan Kita (Our Struggle), which was intended to explain the Prime Minister's ideas, was hardly heard of outside Jakarta. A complete lack of understanding of Syahrir's policy towards the Allies and the pangrè praja, and about why he seemed to be courting both, separated the pemuda (youthful activists) in places like Pemalang from the central government. So the revolusi social took its course, as we shall see. And when by November local leaders finally had the situation under control and the government running again with newly chosen officials, these efforts were ignored by Jakarta and the provincial government. If Sukarno and the top pangrèh praja in Jakarta had made a gentlemen's agreement of mutual support on September 2, nothing of the sort occurred at the Residency level.33 At this level, a power vacuum quickly developed. Mutual suspicion between the Resident, Mr. Besar, and pemuda groups was heightened because of his late appointment ${ }^{34}$ and because of the kenpeitai

32Soepangat, who was born in Banyumas in 1903, had worked in Semarang before coming to Pemalang as senior medical orderly in the prewar years. He helped to found Pekope at the beginning of the occupation. Subsequent to being imprisoned for more than a year in the aftermath of the Tiga Daerah, he became an official in Soepeno's Ministry of Youth and Development. He was never a member of any political party after the war and died of cholera in December 1958.

${ }^{33} \mathrm{At}$ a speech to the al1-Java and Madura conference of the pangrèh praja in Jakarta, Sukarno had exhorted the latter to get close to the people, while assuring them that in return for their loyalty and support they would be given a "proper place" in the new Republic. See B. R. O'G. Anderson, Java in a Time of Revolution: Occupation and Resistance, 1944-1946 (Ithaca: Corne11 University Press, 1972), pp. 113-14.

${ }^{34}$ Along with the Jakarta municipality, the Residency of Pekalongan was left open when all existing Fuku Shūchōkan (Vice-Residents) were appointed as Residents 
massacre of pemuda in Pekalongan city on October 3 , for which Mr. Besar was largely blamed. He proved unable to exercise real authority or maintain law and order; the police was disbanding in many areas, and the army, for reasons of its own, withdrew its battalions from the three kabupatèn. Before he finally left the Residency on November 12 , however, $\mathrm{Mr}$. Besar had been persuaded to install soepangat formally as bupati in Pemalang and to ratify the appointments of many perjuangan camat and wedana who had been swept into office during the revolusi sosial of October.

The arrival of Sayuti Melik as Sukarno's personal envoy to talk with perjuangan leaders now united in the so-called Badan Perjuangan Tiga Daerah (BP3D) achieved nothing, since he was personally unacceptable to the prewar communist leaders who now dominated the BP3D. Raden Mas Soeprapto, sent by the provincial government to serve as Acting Resident, had little choice but to agree to demands for replacement of the remaining pangrè praja in the Tiga Daerah and ratification of the appointments of all popularly chosen officials. After accepting the appointment of Sardjijo, the BP3D candidate for Resident, at a meeting in Pemalang on December 9, Soeprapto quickly left the Residency. A belated attempt at mediation by the central government by sending in four key members of Prime Minister Syahrir's Socialist Party--namely, Soebadio Sastrosatomo and Dr. Sudarsono (then Minister for Social Affairs) to Pekalongan, and Moerad and Djohan Sjahruzah to Pemalang-proved a fiasco.

Finally, on December 11 , Sardjijo was installed by the social revolutionaries as Resident in Pekalongan. After three and a half days, however, local army units, including those that had earlier been withdrawn from the Tiga Daerah, irked by the imprisonment of their santri commander in Slawi (south of Tegal) and by the placing of guards around the Residency capital, joined with certain angry Muslim pemuda and swept through the Tiga Daerah, releasing imprisoned pangreh praja and arresting over one thousand people. Six nationalist leaders were eventually brought to trial, charged with attempting a coup against the government. The charges were eventually dismissed, and all were released before the first Dutch police action of July 1947.

Having briefly sketched the course of events at the national and Residency leve1, let us now turn to what happened in Pemalang. After the Proclamation, a group of moderate nationalist politicians and officials calling itself the Panitya Persiapan Kemerdekaan Daerah Pemalang (Committee for the Preparation of Independence in the Region of Pemalang) began to suggest flying the Merah Putih (Indonesian flag). Because this group, which included Abdul Mutholib, was close to the town's pangreh praja, there was no opposition from the latter--a situation contrasting sharply to what transpired in Brebes, Tegal, and the

on September 5, 1945. See Koesnodiprodjo (ed.), Himpunan undang-undang, peraturanperaturan, penetapan-penetapan pemerintah Republik Indonesia, 1945, rev. ed. (Jakarta: Seno, 1951), p. 88. The reaction to this was a special motion of support from the Pekalongan National Committee. Mr. Besar's appointment was finally ratified by Jakarta on September 21. Jakarta's hesitation seems to have strengthened suspicions about Mr. Besar's Republic credentials among perjuangan leaders and the pemuda throughout the Pekalongan Residency. 
Residency capital itself, where priyayi officials either refused or actively opposed pemuda demands that the Merah Putih be flown in front of all government buildings. In Pemalang the Japanese flag by the kabupatèn was hauled down for good on September 10.35

A similar group made up the kabupaten's KNI (Komité Nasional Indonesia, Indonesian National Committee). Unlike its counterpart in Tegal, where pemuda leaders were strongly represented, the Pemalang KNI was dominated by priyayi officials. The chairman was the patih (deputy to the bupati), with Abdul Mutholib as first vice-chairman, and the wedana of Belik as second vice-chairman. It also included some of Pemalang's prominent conservative santri leaders, and several moderate nationalist politicians. The full group, eight in all, seems to have been appointed by the bupati, R. T. A. Rahardjo Soeroadikoesoemo, rather than chosen by acclamation at pemuda meetings as occurred in Tegal. This KNI was never to be more than a paper organization. It does not seem ever to have had an office, and at least two other prominent members of the Pemalang perjuangan say that they either "knew nothing of it," or that "it didn't exist." Abdul Mutholib was apparently the only "active" KNI member, making trips into villages to te11 the people that "they had to demonstrate social orderliness ["harus menunjukkan tertib sosial"]."36

Rather than the KNI, it was four loosely knit pemuda groups that sprang up in active response to the dramatic developments in Jakarta and the lack of enthusiasm in the Residency capital: GPAI (Gerakan Pemuda Arab Indonesia, Movement of the Arab Youth of Indonesia); Laskar Pemuda Tionghoa (Chinese Youth Irregulars); Hizbullah (Army of God); and API (Angkatan Pemuda Indonesia, Indonesian Youth Generation), of which the last was by far the largest.

The GPAI was organized exclusively by the town's Arab pemuda. Its treasurer, a former Persi activist, describes its purpose thus: "We wanted the Arab group to organize itself, to provide its own leadership; we didn't want to be led by others. We didn't even have any connection with Hizbullah."137

This separateness of the Arab community was partly physical; the Arabs lived in the so-called kampung $A r a b$ and prayed in their own mosque, quite apart from both the Muhammadiyah group in Sirandu and the santri rakyat of Pelutan. But it was also ideological, for the Pemalang Arab community was strongly influenced by the Al-Irsad, the most progressive of the prewar Arab educational movements, which ran a school and a scout group in Pemalang.

About 30 Chinese youths between the ages of 18 and 22 , a11 educated at the local Tiong Hoa Hwee Kwan (Chinese-language school), were organized in the Laskar Pemuda Tionghoa. Like most other badan perjuangan (resistance organization) leaders in Pemalang, the Laskar

\footnotetext{
35Soegriwo Poedjooetomo, "Ikhtisar Perjuangan Politik dari thn. 1940 sampai akhir 1949 di Daerah Pemalang Selatan" (typescript).

${ }^{36}$ Transcript of taped interview with a former Pemalang perjuangan leader in February 1975.

37Interview in February 1975.
} 
leaders Tan Djing Kwan and Tju Liep Goan had been active before the war in Pomer, and Djing Kwan was a close friend of API leader Soepangat.

Hizbullah, formed towards the end of the Japanese occupation, coordinated many of the town's Muslim pemuda. Like the GPAI and the Laskar Pemuda Tionghoa leaders, its leaders, Haji Bushaeri and Nur Effendy, had no sympathy with the so-called "corrupters," the priyayi officials.

It was API, however, which coordinated the majority of the town's pemuda. As we have seen, its leader Soepangat had emerged by the end of the occupation as the town's leading nationalist figure, backed by the santri rakyat of Pelutan, the PKI underground, and most pemuda elements. In the period after the Proclamation Soepangat continued to be respected and trusted by the pemuda as they organized into the groups mentioned above. The only opposition came from the sma11 Angkatan Muda (Young Generation), most of whom were sons of the town's officials. (In many ways this conflict actually had its origins back in earlier rivalries between the leaders of Kopi and Pekope.)

API's organization was divided into four so-called markas (headquarters). Markas I, initially located at Soepangat's house, had essentially political functions. It was composed of many of the prewar pergerakan leaders from Partindo and the KBI, as well as an older group of former Sarekat Rakyat members who, like Amir, had been imprisoned in Boven Digul after the communist uprising of 1926. During the revolusi sosial of October, Markas I was to move from Soepangat's house into the Assistant Resident's offices on the east side of the town square. There, under Amir's tutelage, an asrama (barracks) was started and pemuda were given military training and political indoctrination. Markas II, located near the morning market, was responsible for security of the town in general, and of the market in particular. Markas III handled API's finances. Like the other badan perjuangan, API relied heavily on contributions from the town's business community. But since in Pemalang this community was dominated by Arabs, Chinese, and santri, the GPAI, LPT, and Hizbullah had obvious advantages in raising money from this source. Accordingly, Markas III tried to raise funds by putting on plays.

These plays, put on by Markas III throughout the period of the revolusi sosial until early December 1945, were staged at the Indra Picture Theater. The sri panggung (star) was a young girl called Riftha, who sang songs of the revolution reminding the youth of their responsibilities. One favorite was Sumpah Pemuda (Oath of Youth), the first line of which ran "Sumpah pemuda menjadi kewajibanku [The oath of youth is my duty]." Tickets sold for 25 cents, 50 cents, and one rupiah. Three lakon (stories) came to be played in rotation, changing every two nights. The first was Diujung Bambu Runcing (At the Point of the Bamboo Spear), about the unity of the pemuda rakyat (youth of the common people), whose only weapons were bamboo spears. The second was Untung Suropati, about the career of the famous late seventeenth century Balinese hero, who fought against the VOC in Java. The third, composed in November, was Didepan Kawat Berduri (In Front of the Barbed Wire) and told the story of the British assault on Surabaya on November 10. One of the leading actors recalls: "These plays were in Javanese, written by a certain Sumito, who was steeped in mysticism and very clever at composing. The tambur [band] was referred to as the 
jazz band and was very popular. Every night was ful1."38 Aside from helping to raise funds, these plays also helped to promote a kind of separate pemuda identity. From the plays, young people could learn that to be a pemuda meant to be active for the revolution, to wear one's hair short, and to have clothes that were sembarangan or any old how (such as wearing odd shoes).

Markas IV acted as a kind of social welfare office. A former member of Markas IV remembers:

The pemuda would bring in poor people from the kampung to receive a quota of cloth. They had to come in person, as the cloth would not be distributed elsewhere by the pemuda. The people who came were asked their name and work, and their kampung, and we told them that the cloth had to be used by them and was not to be sold. I had to guard the distribution and no one was dishonest; if two meters per person was being given out, then it was exactly two meters, no more and no less. ${ }^{39}$

But in addition to distributing cloth, Markas IV also attempted to control all economic activity within the kabupaten. The same API member continues: "Any goods sent into the kabupaten capital were detained. Markas IV was informed and it reported to Markas I. Markas I then decided whether the goods were needed for the perjuangan or not. If they were needed, they were bought at two-thirds their value; there was no extortion."4o Similarly, goods could not leave the kabupatèn without permission from the leader of Markas IV.

One of the pemuda's main tasks was to organize the town security, and here too API proved more effective than the other badan perjuangan. As compensation for turning up for guard duty, its pemuda received nasi ponggol (rice wrapped in banana leaves) cooked at a public kitchen (dapur umum) where many of the activist girls were assigned. In fact, nasi ponggol was no better or worse than everyday food, but it (or the workers at the dapur umum) caught the imagination of the pemuda and came to be a symbol of the revolusi sosial.41

As the social revolution developed, several typical characteristics of being a real pemuda emerged. People say one had to join (harus turut) in turning up at the markas for guard duty. No one ever ordered one to do this; it was part of the pemuda consciousness to understand the need to do guard duty ("jiwa insyaf terhadap keamanan").42 (But anyone not active was quickly suspected of being "the enemy.") A pemuda was someone with enthusiasm (semangat), and this was more important than age, sex, education, or marital status (although few in fact were married). If they had semangat, even people more than fifty years old or with established status were said to have youthful blood (darah pemuda).

$$
{ }^{38} \text { Interview in February 1975. } \quad{ }^{39} \text { Interview in February 1975. }{ }^{40} \mathrm{Ibid} .
$$

${ }^{41}$ However, some pemuda were reluctant to relieve their fellows on guard duty if the nasi ponggol had not arrived, leading one pemuda leader to refer to them cynically as pemuda ponggol.

${ }^{42}$ This distinguished the pemuda in Pemalang from the rakyat biasa (common people), who weren't aware of the importance of security. 
On the other hand, one was free ( $b e b a s)$ to come and go when one felt like it, nothing should be too organized, each person was seeking his own freedom ("masing-masing mencari kebebasan sendiri"). As a Hizbullah leader recalls it:

The pemuda wanted freedom [kebebasan], yet didn't understand, and weren't much concerned with the meaning of independence [kemerdekaan]. They were more concerned with military drill [barisberbaris] and sowing seeds of hate against the Dutch [menanam benih ketidaksenangannya terhadap Belanda]. What did the pemuda talk about? Only one thing, defending the country [membela negara]. ${ }^{43}$

The use of nicknames (wadanan) referring to physical traits or eccentric behavior was common in Pemalang during the social revolution, and reflects the links that developed between the pemuda and certain radical older pergerakan leaders. Wadanan were originally used as a kind of code between members of the prewar radical underground, particularly those in prison, for protection against Dutch spies. Normally such epithets used pubiicly would cause shame or embarrassment because they usually referred to physical flaws. But in the Pemalang perjuangan, one had to have the courage to be nicknamed anything ("harus berani diwadani"). For example, Jono cempluk was so called because he was short like a small lamp (cemplik) with a round protruding stomach (nyempluk); or the man known as Karso gebog because he was short and slightly plump like the gebog, a small storage place for poor farmers' paddy; or Amir codot, the prewar communist leader, who gained his nickname because his favorite food was bananas, like the codot bird. The fact that the pemuda picked up the wadanan style reflects their trust in and admiration for the older radicals. ${ }^{44}$

The special nature of pemuda solidarity in Pemalang in this period can be seen in the membership and role of Pesindo (Pemuda Sosialis Indonesia, Indonesian Socialist Youth), the name API took after midNovember.45 It is striking how those who remember the period today emphasize the way in which Pesindo unified all groups. Aliran and ideology were unimportant in the struggle against the common enemy. The ex-head of the information section of Pesindo in Randudongkal recalls:

A big sign, PESINDO, was put up outside the pemuda headquarters in Randudongka1. I went once as a delegate to a Pesindo meeting in the Agung theater in Pemalang with Kyai Said from Gendoang. But we only discussed social, not political problems, e.g., about organizing food for the pemuda and about clothing for the people. ${ }^{46}$

But pemuda unity was not only a matter of common generalized goals. Pemalang Pesindo leaders were also not at all selective about whom they approved as leaders of local Pesindo groups. It must have

\footnotetext{
${ }^{43}$ Interview with a former Hizbullah leader in December 1975.
}

${ }^{44} \mathrm{At}$ the time of the social revolution, Soepangat himself was over 40 , Amir was 38 , and the Hizbullah leader Bushaeri was well over 30 .

${ }^{45}$ This followed the formation of Pesindo at the national pemuda congress in Yogya on November 12 .

${ }^{46}$ Interview with former Randudongkal Pesindo leader in November 1975. 
been obvious at times that certain people were forming Pesindo branches mainly to protect themselves from the revolusi sosial going on around them rather than to support it. Thus in the subdistrict of Petarukan, a subbranch of Pesindo was set up in Kendalsari, one of the richest villages in the entire kabupaten. (In the Dutch period, when bicycles were still few in number--at most ten in a village--Kendalsari landlords already owned cars.) Its leader was the son of a man who had been lurah during the Japanese time, who had three wives, and whose family owned 162 bau of rice-land. Pesindo office-holders in Kenda1sari were all related to one another and all came from landlord families. They and the Kendalsari pemuda who joined Pesindo (all of whom were Dutch-educated) did so, as one local perjuangan leader put it, "simply and solely to save their families from being disturbed as a result of rapid social change [semata-mata untuk menyelamatkan keluarga dari gangguan akibat perobahan sosial yang cepat]." It is possible that the Pemalang Pesindo leaders approved the Kendalsari subbranch leadership in the expectation of tapping the village's wealth to he1p other areas. If so, these expectations were certainly frustrated. As the ex-secretary of Kendalsari Pesindo (half guiltily) remembers: "Five sugarcane railway trucks, then two more, each with a capacity of twenty quintals, arrived from the Comal Pesindo with a request for paddy. However, our leader refused. In fact he had 150 quintals stored away himself, and there must have been hundreds more in the village."47 The fact that nothing happened to the Kendalsari Pesindo leadership over this incident reflects how loosely knit Pesindo was and the lack of real authority of Pemalang leaders over village branches. The truth is that Pemalang leaders simply lacked the trained cadres at the village level necessary for any sustained, systematic social revolution to occur.

Another element in the Pemalang pemuda identity was the intensity of feeling; true pemuda felt things with more intensity than other people. Beginning with the November fighting in Surabaya, the slogan "it is better to bathe in blood than to be colonized [lebih baik mandi darah daripada dijajah]" became popular, and the word darah (blood) became, at least in one rural area, a cry no less important than Merdeka. For some, darah meant "one struggle, one heart," the unity of the struggle against the Dutch. For others, it meant the blood of the colonialists if they dared to come back. It could symbolize the daring of young heroes defending their country; it could also forebode revenge for the bitterness and suffering of the Japanese period.48

Having described the main pemuda groups that sprang up in Pemalang after the Proclamation and briefly discussed their ethos, we may now return to the events in Pemalang themselves. One early problem that faced the pemuda after the Proclamation was what to do with the local Japanese. It is likely that they were galvanized by the kenpeitai massacre of pemuda in Pekalongan on October 3 , for they moved quickly in the week that followed. A leader of the GPAI who took part in the event describes the capture of the town jailer, Yamashita, as follows:

47Interview in November 1975.

${ }^{48}$ The famous Pesindo song Darah Rakyat (Blood of the People) in effect says that the rakyat will come to judge their oppressors. 
An attack was planned on the jailer's house. Some pemuda crept forward on their hands and knees, the way they had been taught in the Keibōdan [Auxiliary Police] and Seinendan training, deathly scared that they would be mowed down by machine-gun fire after what happened in Pekalongan. But some didn't understand the danger and walked casually toward the house. We found it full of yarn for fishing nets! ${ }^{49}$

Yamashita himself turned out to be hiding in the jail. When found by the pemuda, he told them he wanted to be disarmed in the correct fashion by the police. When pemuda called the police, he formally handed over his office and asked to be taken to Tegal.

The other important Japanese was a certain Lieutenant Morishita, the trainer (shidōkan) of the 120-man strong Dai Ni Chūdan (Second Company) of the Dai Ni Daidan (Second Battalion) of the Peta,5o stationed in the old sugarcane factory of Sumberharjo, several kilometers south of Pemalang. Morishita was then living in an old Dutch house on the north side of the square. As one member of Markas IV of API tells the story:

When I arrived in front of the shidōkan's house, about twenty or thirty people had collected from off the streets, wanting to attack. I knew the shidokan personally, he had come to me for watch repairs. We were all afraid that there might be some Japanese fugitives from Pekalongan. We found one firearm and a samurai sword. We took the shidōkan to the police barracks. I don't know what happened to him after that. 51

In the meantime, the pemuda were guarding all the roads going south and west, setting up roadblocks made of bullock wagons to hamper any Japanese trying to escape Pekalongan for the south. But no Japanese were caught.52

If dealing with the Japanese was important to the urban pemuda, the immediate concern of villagers, as news of the Proclamation trickled in, was food. September provided little relief from the hunger and shortages which people had experienced during the occupation. In the southern subdistricts of Pemalang, one former lurah recalls, there were over one hundred quintals of paddy delivered after the last harvest (May-June) which the Japanese had not been able to utilize before the surrender. Demands from hungry villagers that this paddy be

${ }^{49}$ Interview in February 1975. The Pemalang GPAI leaders were particularly sensitive about repercussions to the Pekalongan events as one of their members was among those who had been killed in the kenpeitai-pemuda clash there.

${ }^{50}$ Established by the Japanese in 1943, the Peta was an Indonesian-manned and -officered self-defense force.

51 Interview in Pemalang in February 1975.

52Both the Pekalongan keibitai (city garrison) and the kenpeitai had their regional headquarters in Purwokerto, southwest of Pekalongan. It was thought that any Japanese who escaped would naturally head that way. In fact the Japanese in Pekalongan had already all been disarmed after the Resident of Banyumas, Mr. Iskak Tjokrohadisurjo, had come into town with a Japanese aide and successfully negotiated their transfer to Purwokerto. 
distributed went unheeded by village officials. The tension this policy engendered is nowhere better illustrated than in the subdistrict of Moga. During the first week in October, a meeting was called there while the camat, Singgih Harsojo, was away in Pemalang. The people asked that the paddy be distributed but were told that nothing could be done until the camat returned. The former secretary of the Moga branch of the Badan Pembantu Prajurit53 recalls that:

A large crowd had gathered in front of the noji storehouse demanding the distribution of the paddy. The Fuku Soncho [assistant camat], Deradjat [younger brother of the bupati of Pemalang], got up to speak to the crowd. He was very scared. He said in Javanese, "Sedulur, sedulur émut! [Brothers! Brothers! Be aware!]." The crowd got angry and began throwing big rocks, which missed the assistant camat but fell on the tiled roof which was soon full of holes, though the walls were undamaged. The rocks also hit the tin roof of the shelter in front of the storehouse, then bounced off and rolled down the hill, making a terrific noise. The assistant camat fled--perhaps because of the noise. I told the crowd, "We can't give out the paddy yet!" A voice from the middle of the crowd said, "You're all women here. You can be beaten by just one man!" I moved into the crowd to find out who had said that. It was someone from Jatinegara who had married and settled in Moga--he ran away. By twelve midnight the sound of the kențongan [wooden signal-drum] was far away.54

The next morning, the camat returned and held a meeting to hear reports of what happened. The local teacher Darmowarsito, a Catholic from Magelang, suggested that the camat "arrest the troublemakers." But the camat preferred to begin a campaign to calm the villages:

I was sent by the camat with the lurah of Moga, Haji Mawardi, to villages to give information to the people. The lurah were becoming scared because people were turning up at the kalurahan with sharpened bamboo spears. We sent to Sima village. I said to them, "Be calm, the government will arrange things. Don't take action on your own." 155

As events were to show over the next two weeks, the government had no time to lose in which "to arrange things." By the end of the second week in October it was too late to distribute the surplus paddy. The revolusi sosial had begun.

53The Badan Pembantu Prajurit (Servicemen's Aid Organization) had been set up by the Japanese to help families of those men recruited into the Peta and Heiho (auxiliary forces attached to the Japanese Army). In Pemalang the BP2 a1so provided extra food rations and entertainment for the Peta Dai Ni Chūdan.

${ }^{54}$ This meant that by midnight the disturbances around Moga had died down, and the kentongan signal for emergencies or danger was by then being sounded in villages some distance away. Interviews in November 1975. Jatinegara is a neighboring kecamatan across the border in the kabupatèn of Tegal.

55Interview, November 1975. 
The Revolusi Sosial

The social revolution or rakyat bergerak (people's action) period, as it is referred to in Pemalang, began over demands that paddy be distributed. By early october these demands had still not been met.

On the night of October 7, a large crowd surrounded the house of Raden Mas Hardjowijono, the lurah of Cerih, a village to the southwest just across the Tegal border in the subdistrict of Jatinegara. The lurah, his wife, and 15-year-old son had locked themselves inside, and at $1 \mathrm{a} . \mathrm{m}$. the crowd threatened to burn the house down if the lurah did not come out. Later that morning, October 8 , Hardjowijono finally dressed himself in his full lurah's uniform, faced the crowd, and asked what he had done wrong. He was disarmed and dressed in sacking, while his wife was made to wear a necklace of paddy. Then both were paraded, to the accompaniment of his own gamelan orchestra, the whole five kilometers to Jatinegara. There they were further humiliated by being made to drink unboiled water from half a coconut shell and to eat rice bran.56 Then the lurah and his family were imprisoned in the kecamatan office so that the local perjuangan leaders, including a new camat, could keep an eye on them.

Two days 1ater, in Warungpring, across the border in Pemalang, the house and store of a Chinese trader, Oei Tjun Lum, was burned to the ground. When news of this incident reached Moga, the subdistrict capital, Moga's only bus was chartered by local officials to go to inspect the damage. The next day, Thursday, October 11, 1945, was market day. Early in the morning a crowd arrived in Moga parading a person with corn cobs and young jackfruit around his neck. As it was market day and many people were coming into the town, the crowd gathered in strength as it proceeded. Kyai Said from Gendoang, the leader of the group, was carrying the heirloom (pusaka) of Mandirejo, a kris called Kyai Pokal,57 sheltered by an umbrella. When they entered the yard of the subdistrict office, the camat, Singgih Harsojo, came out and asked what they wanted. "This man was stealing corn [Wong si nyolongi jagung]," they said. The camat stepped forward and said, "Why have you brought him here like this? You should have handed him over to the lurah." At that point, the crowd surged forward and someone struck the camat in the face with an axe. He ran for the telephone outside the office, but it was pushed off the table and fell to the ground. While running away from the kecamatan, covered with blood, he was hit by a stone and fell in the mud, but finally managed to pick himself up and get away.58 As Singgih Harsojo told it 30 years later:

Someone hid me behind a rice mortar. After I had been lying there for a couple of hours, a neighbor came and smuggled me into a nearby rice barn. I slept for a time and then must have passed out altogether until about $6 \mathrm{a} . \mathrm{m}$. the next morning. Then I crept out and

56 Interview with the son of the former lurah of Cerih in February 1975.

${ }^{57}$ Candi Mandirejo was a sacred grave in Moga. People who had Mandirejo blood were supposed never to work for the Dutch; and there was a belief that if any pangrèh praja saw Kyai Pokal he would be dismissed from his job.

${ }^{58}$ This account was given my informant (who had left Moga earlier in the day) by a Chinese shopkeeper who was there at the time. It is not an eyewitness account. 
walked along the road towards Pemalang, but after a while I fainted again. Luckily, someone took me to the local hospital and later to Pemalang. 59

It was widely believed that Kyai Said had used the clever deception of bringing a thief "caught in the act" to lure the camat out to meet the crowd. The necklaces made of the "stolen goods" were a particularly effective element in the ruse. The rest of market day in Moga saw the ransacking of the houses of eleven people who were prominently involved in the distribution system during the Japanese occupation.

Kyai Said's action in parading his "thief" up to the subdistrict office set a pattern which was to be repeated against many lurah all over Pemalang in the next two weeks. But in every other case the thief was a "real" one. Such actions went under the name dombrèng. The word dombrèng comes from tong and brèng, two onomatopaeic Javanese words for the sounds of banging on wood or metal. Thus to be dombrèng-ed during October 1945 in Pemalang and Tegal meant to be paraded around to the accompaniment of clanging tin pots and wooden clappers. "Tong, tong, tong" is also the sound of the kentongan, the signal-drum which, depending on the number of beats and the rhythm, can be used for calling meetings, giving the time, or warning of fire, theft, or other emergencies. It is quite possible that in some cases the thief was paraded to the sound of the "thief kentongan," broadcasting loudly that "here we have caught a thief!"

Here is another eyewitness account of a dombreng action, this time in the kecamatan of Ulujami. It was a Wednesday in October and the kecamatan's eighteen lurah had assembled for a meeting at about $10 \mathrm{a} . \mathrm{m}$. Then a parade $\left(a r a k^{2} a n\right)$ coming in from the east approached the kecamatan office. Soenarjo, a member of the prewar pegerakan and secretary of the Ulujami Indonesian National Committee, who was at the meeting, describes the scene thus:

The crowd of people all had bamboo spears and were accompanied by banging on empty kerosene tins, "brèng dong brèng." When the crowd got closer, it appeared that the lurah of Rowosari, Muhadi, was in the middle. His face was smeared with lamp soot and he was wearing a necklace of paddy. The parade almost dropped in at the kecamatan, but for whatever reason this didn't happen. This put all the lurah into a great panic, the conference ended in confusion, and they hurriedly returned to their respective villages. ${ }^{60}$

A typical dombrèng action usually followed this scenario: A crowd, mostly "țung dung brung-ers,"61 arrives at the house of the

${ }^{59}$ Singgih Harsojo's version is that he was wounded in the face by a bamboo spear as he went to the aid of the kecamatan secretary, who was being overwhelmed by the crowd. His account does not mention the thief ruse, though other versions do. Interviews in November 1971.

${ }^{60}$ Interview in November 1975.

61In Pemalang, calling someone a "tung dung brung-er" means saying he is ikut2an, not actually an opportunist, but a "mindless follower" who comes running to see what all the fuss is about whenever he hears the sound of the signal drum. 
person who is to be dombrèng-ed. They break into the person's house. If the person is found, he is taken out, presented to the crowd and paraded around, often with a necklace of hulled rice or paddy, to the "brèng dong brèng" of empty tins and sticks being beaten. This always occurs during the day so that the maximum number of people can see the "corrupter," and he will be as humiliated as possible. The essence, then, of these dombrèng actions was a symbolic, public unmasking and shaming of officials rather than intimidating or killing them. But it was not only officials who were unmasked. In Temuireng village on the coast, for example, a man was dombrèng-ed for having intercourse with his stepdaughter. In Sirangkang, in the same area, a pemuda was caught gambling. The cards were made into a necklace and he was paraded around the village by Pesindo.

From Moga, the chain of popular actions against hated officials spread north, and south to the hill district of Belik. Mostly, the demand was that paddy be distributed. Hardjowinoto, the wedana of Belik, had gone to a meeting in the village of Bulakan. He tells what happened as follows:

I entered the yard on horseback and saw the sharpened bamboo spears hidden in the fence. That made me feel rather frightened, but I went on, dismounted, and met the crowd. They were all asking for the paddy which they had been forced to sell to the government. I told them, "It doesn't belong to me. I cannot give you the paddy without an order from my superiors. I am only an ordinary official." So I told them, if they didn't want to wait for an order, to go ahead and distribute the paddy, but that it was their decision, not mine. They formed a committee and I advised them not to have any village officials [junjang krawat] on it.62

The position taken by the wedana of Belik to "wait for orders" from above was common to all pangreh praja of Pekalongan Residency during September and october 1945 and reflected the timidity, lack of initiative, and obsequiousness fostered by their Dutch bureaucratic training and feudal backgrounds. Surviving local perjuangan leaders are convinced that one of the reasons for the revolusi sosial was the failure of the central and provincial governments to inform local pangreh praja about the policies of Jakarta or about the guarantees of cooperation their own spokesmen had given to Sukarno in september. Left on their own, not knowing what the government wanted them to do (e.g., distribute the paddy or not), they reacted in the only way they knew, by waiting for orders from above.

The wedana of Belik later met a larger, different crowd of some hundreds on its way to the central paddy storage place in Belik. Taking a back route to Belik to get there before the crowd arrived, he remembers what happened as follows:

In every village you could hear the sound of the kentongan titir, the most urgent signal--a ceaseless, fast, even beat warning of

62Transcript of taped interview in May 1973. (The term junjang krowat is used only in certain areas away from the central courts of Yogya and Solo to refer to punggawa désa or village officials. W. J. S. Poerwadarminta, Baoesastra Djowa [Jakarta: Wo1ters, 1939], p. 96.) 
danger. The lurah accompanying me wanted to go home. He was afraid for the safety of his family. Then a former member of the Keibodan showed me the quickest way back to the kewedanaan. It seemed everyone had left. Someone met me saying it was too dangerous to return, but I wasn't anxious. What happens is preordained [takdir] anyway. . . As I got nearer someone called out "Merdeka!" I was relieved; that meant I still had some authority. ${ }^{63}$

The greeting "Merdeka" that the wedana received from the people was a greeting of friendship, not enmity. He was not one of the pangreh praja believed to have bought rice up cheaply during the occupation, or to have traded illegally in fish confiscated on its way up through Belik to Banyumas. At least one person was prepared to defend him physically:

A Chinese stepped forward out of the crowd. I recognized him, he had come to me for help during the Japanese time, as the camat was forcing him to pay Rp. 150 as a Foreigner's Registration Fee or be sent off as a forced laborer [römusha]. I had told him then to say, if asked, that he had paid me the money, as I knew the camat wouldn't dare check up. The Chinese said that if anyone dared come near me, he would stab them himself. 64

In the three southernmost kecamatan--Belik, Watukumpul, and Pu1osari--the mildness of the social revolution is apparent. Fewer lurah were replaced than along the coast. Although these areas had been extremely poor since Dutch times (it will be remembered that the Mardi Utomo was formed in and for Pulosari), the santri oppositional element was missing. Being very poor abangan, the villagers could neither afford nor were as keen to send their sons away to traditional Muslim schools (pesantrèn), as peasants did in Moga and Randudongkal. Not only were there no santri leaders from the pergerakan, such as Kyai Said in Gendoang, there were also no lenggaong villages in these subdistricts.

In the town of Pemalang, the social revolution was characterized by a night of upheaval in which the houses of a lurah and the camat of Pemalang were set on fire, and many others looted. The actions were sparked off by the lynching of Djoewito, a former agricultural officer who had been responsible for the distribution of cloth during the occupation. Djoewito had been having a meal at the market, not knowing that a crowd was waiting for him outside. As he left the market on his bicycle he was stopped and killed with a hammer blow on the head.65

That night crowds roamed the streets of Pemalang looking for "corrupt ones." In the words of an API leader: "The people were parading around wearing only shorts or loin cloths [cawat], their bodies blackened with lamp soot. They wore old tires around their necks which were taken off and cut up to make torches, so they could see their way."66 About $10 \mathrm{p} . \mathrm{m}$., a mob arrived at the kabupaten, but found

${ }^{63}$ Ibid. 64 Ibid.

65From interviews (all secondhand accounts) in Pemalang in February and November 1975. I have no eyewitness account of Djoewito's death.

${ }^{66}$ Interview with a former leader of API in February 1975. 
no one home; a pemuda leader had persuaded the bupati to lie low.67 The crowd then went to the house of the kabupaten secretary, which was broken into and ransacked.

Other leading priyayi officials known to be corrupt were singled out that night. For example, the house of the wedana of Pemalang, Wijogo Puspojudo, "who coughed continuously and had a young second wife," was sacked. The home of Wadri, the head of the Fisheries Department, met the same fate. One Pemalang priyayi, who was in the perjuangan, remembers: "Wadri! That bajingan tengik [rotten-smelling petty thief]! He married the bupati's sister-in-1aw, a widow, so that he could say, 'I'm married into the bupati's family.' I was riding a bike with solid rubber tires, while he was hoarding tubes--he had a whole room full!"68

At least one pangreh praja from the rural areas was in Pemalang on that night, having earlier been the target of similar action in his own locality. The ex-camat remembers:

We had left all our belongings behind in Bodeh, had arrived in Pemalang, and were staying in the house of a teacher named Umar. We had just finished dinner about $7 \mathrm{p} . \mathrm{m}$. when a crowd came past the front of the house and stopped. Small children were carrying petromax lamps and small red and white flags, and beating on empty cans, "țong țong țong." Then I remembered that Umar had been a kumichō and responsible for the distribution system of his neighborhood association. The mob surrounded his house and tried to enter it, shouting, "Burn! Burn!" We managed to move ourselves and our belongings to the house of the next-door neighbor, Kyai Abdullah. Someone said, "It's not the house but the man that we want." Then Umar's house was ransacked and we lost our bicycle and all the belongings that we had brought from Bodeh. Apparently, Pak Umar knew what was going to happen as he had moved his sewing machine and other goods beforehand. 69

Natsir, the Pemalang police chief, was among those whom the town's pemuda kidnapped that same night for their own safety. Here is his wife's account:

During the night he got up and went out to relieve himself, dressed only in a sarong and a singlet, and didn't come back. I hurried to the police barracks, but he wasn't there. Then I went to the pemuda headquarters and was told he was in the jail. I was allowed to see him. He said he had been held up by a man with a pistol. The next day about ten pemuda came to our house. They took all the Dutch books from the shelves, carried them outside and made a bonfire of

67A leader of GPAI recalls: "I found the bupati in the Langgar [smal1 Muslim house of worship] near my house. I asked him, 'What are you doing here, sir?' He replied, 'I'll just stay here for a while. There won't be any problem.' Then I talked to an Arab called Ali and found out that the kabupatèn had been attacked and the patih's house set on fire."

${ }^{68}$ Interview in February 1975.

${ }^{69}$ Interview with former camat of Bodeh in September 1971. 
them, saying this was evidence Pak Natsir had been a NICA [Netherlands Indies Civil Administration] agent. They said it wasn't safe for me there and that they would take me to "safety."70

Mrs. Natsir and the wives and families of all the town's top priyayi officials were taken to the former residence of the Japanese shidokan on the north side of the town square. A perjuangan leader today claims that only those families who were willing were moved to safety at the shidokan's house. The bupati's wife, however, was among those who considered themselves interned:

I took the kabupatèn heirloom with me, a small kris called Bah Tapah. Every night it was washed, the water was kept overnight in a refrigerator and the next day sent in three thermoses to the prison. One was for the guards, so that after drinking they would not be too harsh towards the prisoners; the rest was to give my husband peace of mind while he was in prison. ${ }^{71}$

Haji Bushaeri, the Hizbullah leader, remembers that "al1 the officials accused of being corrupt were rounded up, had their hands tied above their heads, and were taken to the tennis court in the town square."72 Between sixteen and eighteen of the town's officials were put in jail, the only place where their physical safety could be guaranteed. They included the bupati; Soemarto, the patih; Natsir, the police chief; Wijogo Puspojudo, the wedana of Pemalang; Sukardis, the head of the Public Works Department; Wadri, the head of the Fisheries Department; "Meneer" Umar, the teacher and kumicho; and Raden Soewignyo, the kabupaten secretary. Abdul Mutholib, whose name was at the top of the pemuda blacklist, was able to make a dramatic but temporary escape with the help of a pemuda who, although a member of API, also belonged to Muhammadiyah and was Mutholib's neighbor. Mutholib had gone into hiding earlier in the day at the camat's house but had later been moved (luckily, for his sake) to this pemuda's house. The latter recalls:

The pemuda said, "Whoever is hiding Mutholib will be killed." When the disturbances had died down, we left by bicycle at about $2 \mathrm{a} . \mathrm{m}$. with Mutholib on the back. He was very nervous and very scared. "Hidup mati ditangan dik Ali [My life is in your hands, little brother Ali]," he said. He was on the back because he was so frightened that he reckoned his legs were too weak to pedal, although he weighed between 95 and 100 kilograms while I was much lighter, and he should really have been carrying me! At Bojongbata [south of Pemalang] we were stopped by the village secretary, Denin. Luckily he knew my voice. I said that Mutholib was my older brother. We finally arrived at the small station of Babatan, having ridden the seven kilometers in about an hour. ${ }^{73}$

Later that morning Mutholib boarded the train to Tegal, but on the way he was recognized by some Arab pemuda and taken back to Pemalang. There he was handed over to the GPAI markas and ended up on the tenniscourt with all the other prisoners. This is the place perhaps to point

\footnotetext{
70Interview with Mrs. Natsir in September 1972.

71 Interview with Mrs. Rahardjo in December 1971.

72 Interview in November $1975 . \quad 73$ Interview in February 1975.
} 
out that Pemalang was unique in the Residency in that santri pemuda from both the GPAI and Hizbullah played a major role in the early part of the social revolution. As the pemuda deputy leader of Hizbullah at the time put it later:

The main purpose [of the pemuda], including the religious group, was to oppose the corrupt ones, "Meneer" Umar, Wadri, and their crowd. Ideology was not important then, nobody thought about ideology, at least the Islamic group didn't. There were no orders, that is why semangat and spontaneity were so important. Someone would point their thumb in the direction of the next house. Everyone would understand and head for that house. At that time, like no other period during the revolution, we were together, we were one. We also didn't know anything about politics [buta politik] in those days. Certainly, the Islamic group was. Most of the leaders of the pemuda brigade were santri. We were united then with the one aim of destroying the corruptor cliques. ${ }^{74}$

The next morning a mass meeting was held in the town square, where Soepangat spoke. He told the people that there must not be any more arson and that no one should be killed. The fact that Soepangat's call for order was obeyed highlights an important difference between the social revolutionary movement in Pemalang and its counterparts in Tegal and Brebes.

While the latter two movements were fragmented in several ways, Soepangat was able to forge a remarkable unity between his own group of prewar secular nationalists, younger pemuda figures, and the santri leaders. He had begun this work in the Pekope and was to continue it until the end of the Tiga Daerah Affair. The relative absence of violence in Pemalang, however, was also due to the fact that the rural lenggaong in general followed Soepangat's leadership, and as for urban thieves (pencoleng) and troublemakers (tukang tèțèk-bengèk), Soepangat controlled them through a well-known pencoleng called Madrei, who was imported specially for that purpose from Randudongkal. A former leader of API's Markas IV recalls: "The remarkable thing about the period of Soepangat's rule in Pemalang was that there were literally no thieves, pickpockets, or troublemakers operating in the town. They all followed Soepangat's leadership."75 The former leader of the Laskar Pemuda Tionghoa attributed Soepangat's success to his reputation for honesty and fairness in running the pekope rationing system. He was also well liked by everyone because of his tactful flexibility (kasupezan), and he was closer to the pemuda than many pemuda leaders themselves.

Let us now turn to the subdistricts to the east of Pemalang, and look briefly in turn at what was happening at the kecamatan level in Petarukan and Taman, and at the village level in Bumirejo and Ambowetan (Ulujami).

In Petarukan the sugar factory was taken over by Sidris, a famous lenggaong and leader of the Barisan Céngkrong (Sickle Corps). This band of brigands (jago) used to ride about on bicycles with long

74Interview in February 1975. $\quad 75$ Interview in February 1975. 
sickles, carrying out actions against many lurah.76 After Sidris was appointed factory administrator the camat went into hiding, for fear of him; several days after the factory had been taken over, a new camat was appointed. The former secretary of a local Pesindo branch describes what happened:

Thousands of people had gathered at the Petarukan soccer field. The local school teacher Soedaju had been "carried" [digandèng] to the field from his house. Sidris held up a sickle in his hand and announced, "I am now the sugar factory administrator [besar pabrik]. I announce that [Soe]Daju is appointed Assistant Wedana." Tears were trickling down Soedaju's face. Then the old assistant factory head Ismail ceremoniously handed over the factory samurai sword. Ilham, a local leader of the prewar pergerakan, was elected as police agent [mantri polisi], and Sidris's brother as head of the subdistrict office. Ilham then said that any other officials would be appointed when needed. 77

Meanwhile, the old camat Soejatno had managed to get a letter to Soepangat's wife, a distant relative, explaining his plight. In the town of Pemalang the perjuangan leaders thought that he had been killed. However, he eventually managed to escape from Petarukan with the Kendalsari Pesindo secretary:

I left at $1 \mathrm{a} . \mathrm{m}$. with Soejatno on the back of my bicycle. I was armed only with a chain used in kuntau sizat [self-defense art]. ${ }^{78}$ Raden Parno was with me and he had a keris pedut; he kept one hand on the handlebars and one hand on the kris (it was a special kris which made you invisible). At $3 \mathrm{a} . \mathrm{m}$. we arrived in Banjardowo. We were stopped by Li Cing, a follower of the main leader of the perjuangan there, but were allowed to go on (this was because of the power of the kris). We arrived at the house of the new patih, Dr. Muriawan, but the Pesindo guards didn't seem to notice us, and we weren't challenged, so we went to the back door and knocked. Dr. Muriawan opened it with his left hand. In his right hand he held a pistol. He embraced Soejatno, saying, "We heard that you had been killed."79

Soejatno went into hiding for several weeks in $\mathrm{Dr}$. Muriawan's house and was then appointed as kabupaten secretary. Here again Soepangat demonstrated his authority and skill. It was not popular to use officials of the pangreh praja, but Soepangat believed it was necessary to keep the wheels of government moving, and he had the authority to make his view stick. It is interesting that the ousted camat of Ampelgading was also employed in the new kabupaten administration. In reply to the cry of the more radical element in the town's perjuangan (the

${ }^{76} \mathrm{On}$ the role of the jago in the rural revolution in West Java, see John $\mathrm{R}$. W. Smail, Bandung in the Early Revolution, 1945-1946, Cornell Modern Indonesia Project Monograph Series (Ithaca, 1964), pp. 123-25.

77 Interview in November 1975.

${ }^{78} \mathrm{Kuntau}$ is a combination of two Hokkien words: kun, meaning "hand," and tau, "blow." Kuntau silat means a particular type of self-defense art (silat) using the hands.

${ }^{79}$ Interview in November 1975. 
ex-Digul-SR group) who said, "Don't leave a single stooge of the Japanese in," Soepangat and Dr. Muriawan urged, "Let us use the ones who are honest [yang baik dipakai saja]." Not having any formal administrative skills themselves, they felt forced to rely on at least two former camat, one of whom seems to have been strongly implicated in the corruption of the Japanese period.

Gunodo Surio, the camat of Taman, the subdistrict between Petarukan and Pemalang to the east, was the only camat in the entire kabupaten who "escaped" the revolusi sosial--but not because he was not considered "upper class." As the son of R. A. A. Soerio, the bupati of Pekalongan, his aristocratic credentials were impeccable. He was in fact the most well-born of all the camat in Pemalang. He was saved because he was not considered corrupt. In fact, he had worked to alleviate the sufferings of the people in Taman during the Japanese occupation by appointing an honest committee to organize the rationing, and by using the kecamatan cloth quota to make pairs of shorts and sarongs to be distributed to those too poor to get cloth by delivering paddy. Secondly, he had a close relationship with the santri leaders in Taman, and had asked them to give out rice to the local pemuda after the Proclamation. 80

At the district and subdistrict level in other areas the installation of new officials was not as dramatic as the expression of popular sovereignty that occurred in Petarukan. In areas where there had been few dombreng actions, if any, the Pemalang perjuangan leadership was still anxious that the people be given the chance to choose new local officials if they wished. The old wedana of Belik takes up the story in his inimitable style:

Soepangat (I called him Mas Pangat) told me that he had been chosen as bupati. Ha, good luck to him! He said that perhaps the kawedanaan of Belik wanted an election, and could I call a meeting? I said yes, certainly I could. Then Pangat came and told the meeting that he had been chosen as the new bupati of Pemalang. "I am now the bupati of Pemalang, and I was chosen by the people. I have come here because I want to give all the people the same chance. If you don't like your present wedana, you can choose a new one, I will organize it." But the people said: "No, we will keep our present wedana." Then I told the meeting that this was a great chance for them, that there had never ever been a wedana elected by popular choice since the early times. I told them this was their chance to choose someone they wanted. They should not be shy [jangan malu]; if they didn't want to choose me because I wasn't a local person, I would return home. The camat, trying to encourage the people, said the old wedana had had to be called master [ndoro] but the wedana who were chosen by the people could be called father [bapak].81

As the wedana was by himself in isolated Belik, Soepangat offered him a revolver, but the latter declined. "I told him [Soepangat] that if I was given a revolver my behavior might change. Then people who didn't like me might say, 'What is the use of one revolver against all of us?' So I wouldn't take it."

${ }^{80}$ Interviews with Gunodo Surio in December 1971 and a santri leader in Taman in November 1975.

${ }^{81}$ Transcript of taped interview in May 1973. 
Let us now look briefly at the revolusi sosial in two villages in Ulujami to highlight the respective roles played by members of the prewar pergerakan, the lenggaong element and the santri leaders.

The day after the first dombrèng action had been witnessed by the lurah of Ulujami subdistrict at their meeting in the kecamatan (see above, p. 109), an orderly crowd of about 200 unarmed people arrived at the kalurahan of Bumirejo. By this time the lurah and the other village officials had already gone into hiding. The leader of the crowd, a certain Daris from the prewar pergerakan, announced their demand that the lurah and his staff be dismissed because they had helped the Japanese. A set of new officials was then appointed, headed by a new lurah, Rasid, who was a former Sarekat Rakyat school teacher and a veteran of the pergerakan. This new village administration did not last long, however, because it did not reflect the strength of the lenggaong element in Bumirejo. Two days later, the list of officials was changed again to include the son of Siwad, the lenggaong leader, as secretary.82 This second peaceful reshuffie, presided over by the chairman of the Ulujami KNI, reflected the ambitions of Siwad and the other lenggaong from Bumirejo Kidul who wanted Siwad to be lurah.

There were several factors contributing to the orderliness of the revolusi sosial in Bumirejo. First, during the occupation, there had apparently been no paddy searches, and so popular anger was not as high as in other places. Second, there was a strong prewar pergerakan core leadership which could quickly respond to local demands. Thus the crowds which assembled came without bamboo spears, carried out no dombrèng actions, and did not burn or ransack officials' houses. That Siwad was unable to oust the new lurah Rasid was partly because Soenarjo, the secretary of the Ulujami KNI and a veteran of 1926 and the $S R$, was Rasid's brother.83

In Ambowetan events followed a very different course. Containing a large santri group and no members of the prewar pergerakan, the village had suffered harshly during the Japanese times; as a result, the social revolution was a much fiercer affair than in Bumirejo. The lurah's house was ransacked by about one hundred people repeatedly shouting, "Where is the lurah Sayan? [Dimana Zurah Sayan?]." His clothes were taken, and 200 quintals of paddy were distributed, about 20 quintals remaining from the noji and the rest belonging to the lurah himself. Each household received between 40 and 70 kilograms. The crowd was led by a santri called Bunyamin, who had the largest popular following in the village; Kastam, the lenggaong; and Darum, son-in-law of a former lurah and father-in-1aw of Kastam. The old village policeman Wariad, who had been an azachō in the Japanese time, was chased out and fled to the Dieng plateau. Dajani, the bau désa, ${ }^{84}$

${ }^{82}$ Siwad himself had been made secretary during the Dutch time in the hope of inducing him to stop his lenggaong activities.

${ }^{83}$ Interview with Soenarjo; see also his memoir, "Peristiwa 'Tiga Daerah' di kecamatan Ulujami" (typescript).

${ }^{84} \mathrm{~A}$ bau dés $a$ is a hamlet head, called kamitua in south-central Java. 
Table 1. Changes in Village Heads in Pemalang Kabupatèn during the Revolusi Sosial of October 1945 (data from three out of thirteen subdistricts)

\begin{tabular}{|c|c|c|c|c|c|c|c|c|}
\hline & \multirow{2}{*}{$\begin{array}{c}\text { Number of } \\
\text { Villages }\end{array}$} & \multirow{2}{*}{$\begin{array}{c}\text { Number of } \\
\text { Lurah } \\
\text { Changed }\end{array}$} & \multicolumn{6}{|c|}{ New Lurah } \\
\hline & & & Lenggaong & Santri & $\begin{array}{c}\text { Family of } \\
\text { Former Lurah }\end{array}$ & $\begin{array}{c}\text { Former Village } \\
\text { Officials }\end{array}$ & $\begin{array}{l}\text { School } \\
\text { Teacher }\end{array}$ & other \\
\hline Ulujami & 18 & 17 & 4 & 3 & 2 & 4 & 2 & $\begin{array}{ll}1 & \text { trader } \\
2 & \text { uncertain }\end{array}$ \\
\hline Comal & 17 & 13 & - & 4 & 4 & 1 & 3 & 1 uncertain \\
\hline Moga & 18 & $\begin{array}{c}\quad 13 \\
+2 \text { new } \\
\text { lurah } \\
(2 \text { villages } \\
\text { split) }\end{array}$ & 2 & 7 & 2 & 1 & 1 & 5 uncertain \\
\hline
\end{tabular}

Source: Interviews in three subdistricts in February and November 1975. 
was wounded in the head and dombrèng-ed in tears around the village. The old carik Awal lost a set of tables and chairs, 5 quintals of paddy, and 15 kilograms of hulled rice, while the walls of his house were left full of holes from bamboo spears. The noji, a former lurah of Ambowetan, had supernatural powers and a special kris, which enabled him to ward off an attack from Bunyamin wielding a rice-pounder. But his powers did not prevent 25 quintals of rice from being taken, which he admits today he had embezzled during the occupation. He also lost 40 goats, but these were later returned because they were not obtained by corrupt means. ${ }^{85}$

In the new village administration, Kastam the lenggaong became lurah, and the other positions were filled by members of the lenggang group, with the exception of two santri followers of Bunyamin. By contrast to Bumirejo, there was no meeting in which the kecamatan KNI leaders supervised the installation of the new village government.

In some places where different revolutionary factions could not agree, the village split, electing two new lurah. This might have been the outcome in Bumirejo, had the Ulujami kecamatan KNI not stepped in when, after two days, it appeared that Bumirejo Kidul was not satisfied with the first "popular" village government. In Pesucen, in Petarukan subdistrict, where there were fewer active local KNI or members of the prewar pergerakan supervising the choice of village heads, and the lenggaong element was much stronger, the village ended up spiit in two. The old administration fell when a crowd led by the lenggaong Ali Warto and three henchmen ransacked and burned the houses of five village officials. At a meeting then held in the local school, Ali Warto was acclaimed as the new lurah. But he could not hold the whole village under his authority. Part of it split off to form a new village called Selumbu, whose iurah was the former bau of Pesucen. The tanah béngkok was divided evenly between the two new kalurahan. (Ali Warto promptly sold all his newly acquired surplus paddy and gambled the proceeds away at cards.)

Some of the patterns evident in Pemalang's revolusi sosial can be seen in Table 1 , which details changes in village administration in the three subdistricts of Ulujami, Comal, and Moga. The most violent upheavals occurred in Ulujami, where only one lurah, a santri called Haji Sukur, survived in office. (Even he barely withstood a "coup" organized by the lenggaong Deman.) In both Coma1 and Moga the changes were less drastic, but still extensive. At the same time it is notable that in "violent" Ulujami more of the new lurah came from the ranks of village officialdom than was the case in Moga or Comal. The strong santri element may account for the changes in Moga, for many of the new lurah there were local Muslim leaders.

It is instructive that those new lurah in Ulujami who were santri all had their status legitimized by the new bupati of Pemalang, Haji Makmur, after the Tiga Daerah Affair was over. This confirmation of santri social revolutionaries in office was typical, in fact, of administration in the Residency. Perhaps more surprisingly, three of the four new lenggaong lurah in Ulujami survived in office. And in Bumirejo the lenggaong Siwad was able to attain the coveted lurahship when 
Rasid was arrested by the army during the government's December 1945 crackdown on the revolusi sosial.

What all this suggests is that hated established administrators were overthrown almost everywhere. But succession passed to a variety of (and often combination between) counter-elites and pergerakan veterans.

\section{The Aftermath}

The social revolutionary governments in Pemalang, Brebes, and Tegal continued until ear1y December 1945, when they chose Sardjijo as the new "revolutionary" Resident. At a meeting in the Pemalang kabupatèn building on December 9, he was accepted by representatives from the Pekalongan perjuangan. (It will be remembered that Soepangat had already been formally installed as bupati of Pemalang, while Mr. Besar was still Resident.) At that point, the army and the central government moved to intervene decisively. On December 12, the army, aided by Muslims coming mainly from Pekajangan, south of Pekalongan, attacked. There was 1ittle resistance anywhere. In Comal, the troops had a brief clash with local pemuda, and at the Banjardowo sugar factory the Pesindo leader Muharib was killed. At 11 a.m. on Thursday, December 20,86 the military entered the town of Pemalang itself. The local perjuangan leaders were immediately rounded up and taken to the town square. One perjuangan leader from Bojongbata, south of Pemalang, recal1s:

I had just begun my afternoon sleep, when a member of the TKR [Army] arrived. I was told to get up, my hands were tied, then I was beaten in my house; then I was told to run, while I was beaten with a sword handle from behind. I had to run two kilometers to the Pemalang police headquarters, where I was beaten again in my cell. There I stayed for five days. Then I was moved to Pemalang jail, which was full up, and there I stayed for a year. ${ }^{87}$

Other arrests followed, on a fairly massive scale. A former jailer relates that "People were being taught a lesson [dihajar] by the TKR. They were lined up in the town square and whipped until they were half dead. People were screaming, 'Tolong! Tolong! [Help!].' The jail was right on the square, so I could see what was going on."88 Ten days later, on December 30, the town's leading santri, Kyai Makmur, was elected bupati, while Soepangat and his associates were in jail in Pekalongan.89 Soepangat himself was released in January 1947 , but Amir, Tan Djing Kwan, and four others were finally brought to trial in Pekalongan in March 1947, charged with making a coup (makar) or attempting to change the structure of the government by force. All were released shortly before the first Dutch police action in July 1947 .

\section{${ }^{86}$ Diary of Salim Bassiyul. $\quad$ 87Interview in February 1975.}

88Interview in February 1975.

${ }^{89}$ Soepangat escaped south to the Residency of Banyumas, when the TKR entered Pemalang and joined President Sukarno's entourage then touring Central Java. Arriving in Pekalongan with the official party on December 24 , he was recognized by the TKR and local Muslim leaders, dragged out of the reception during Sukarno's speech, and imprisoned along with the other leaders of the revolusi sosial. 


\section{Conclusion}

The immediate background to the social revolution in Pemalang can be seen in the Japanese occupation, with the buildup of tension between the pangrè praja and the people, especially in the rural areas. The former were for the first time forced to play decisive economic roles as the military administration attempted to mobilize Java's resources for the war effort. Rather than trying to soften the harsh impact of Japanese policies, many, indeed probably most, exacerbated it by corruption and extortion. After the Proclamation, the central, provincial, and even the residency governments were too weak and too preoccupied to give support and guidance to the pangrèh praja. These officials took no action to alleviate the severe suffering in the rural areas, waiting inertly for orders that never came.

The beginning of the revolusi sosial was characterized by a special type of social protest known as dombrèng actions. These actions were basically spontaneous expressions of long-suppressed anger against particular exploitative officials. The one camat to survive in his position did so because he had tried with some success to alleviate cruel social conditions during the Japanese occupation.

In some areas the revolusi sosial showed similarities to traditional rural movements in Java, with either the religious leaders or bandit chiefs playing active roles. Yet the general cry "Merdeka!" was part of a modern Indonesian revolutionary ideology, and the revolutionary pemuda, with their slogans and plays, were quite new to Pemalang 1 ife.

But the social revolutionary officials who were swept to power in the wake of the dombrèng actions were unable to achieve much in their attempts to bring about lasting and real social change. The central government gave no support, indeed became actively antagonistic. Pekalongan's initial suspicion turned to open hostility when Sardjijo took over as Resident in December. And, in addition, there was no local social revolutionary armed force which could resist the TKR when it decided to crush the Tiga Daerah movement. (Sardjijo was only Resident for three and a half days before being jailed by the military.)

One abiding result of the revolusi sosial, however, was the removal of many of the old village elite of the colonial era and their replacement by religious elites nationalist leaders, or lenggaong. Subdistrict and district chiefs were genuinely elected by the people for the first time ever. While these changes in Pemalang represented a real transfer of political power, they remained changes at the local level: most of the pangrè praja driven out of Pemalang at the height of the revolusi sosial were given comparable appointments in other residencies by the central government.

One interesting feature of the revolusi sosial is the evident continuity with the disturbances of 1926. Many veterans of 1926 assumed leadership positions in the pemuda-manned badan perjuangan; others became lurah or other village officials after the wave of dombreng actions. As in 1926, the main lines of conflict were not between aliran and aliran, but rather between classes and between rival elites. 
Perhaps the strongest and strangest impression of those involved at the time, however, is the unity that was felt among all members of the perjuangan, whether Islamic- or Dutch-educated, pemuda or nationa1ist veteran. This impression is especially vivid today, because such unity was never again achieved in Pemalang either during the revolution or since. 